\title{
Synthesis of Zeolites from Coal Fly Ash for the Removal of Harmful Gaseous Pollutants: A Review
}

\author{
Xiaoyu Ren, Ruiyang Qu, Shaojun Liu, Haitao Zhao, Weihong Wu, Hao Song, \\ Chenghang Zheng, Xuecheng Wu, Xiang Ga**
}

State Key Laboratory of Clean Energy Utilization, State Environmental Protection Center for Coal-Fired Air Pollution Control, Zhejiang University, Hangzhou, Zhejiang 310027, China

\begin{abstract}
$\mathrm{SO}_{x}, \mathrm{NO}_{x}, \mathrm{CO}_{x}$, volatile organic compounds (VOCs), and $\mathrm{Hg}$ vapor directly and indirectly harm the atmospheric environment and human health by contributing to the formation of photochemical smog, acid rain, and haze and posing risks of potential toxicity (e.g., carcinogenicity). Therefore, effectively controlling and reducing the pollution caused by these chemicals is critical, and to that end, several methods have been developed, among which adsorption is one of the most common and effective techniques. As adsorption materials, zeolites show great potential in reducing air pollution. Moreover, coal fly ash (CFA)-based zeolite synthesis enables the simultaneous treatment of air and solid waste pollution. In this study, the progress of recent years in research on zeolite synthesis by CFA is reviewed, and the challenges besetting this method are discussed. In addition, we examine the application of CFA-based zeolites in removing or minimizing harmful gases. As we enter an era of utilizing disposed waste, developing efficient and low-cost materials for the removal of harmful gases may require improving the synthesis of high-purity, high-performance fly ash zeolite materials.
\end{abstract}

Keywords: Coal fly ash; Zeolite; Synthesis; Gaseous pollutant; Removal.

\section{INTRODUCTION}

Coal is the second largest fuel in the global energy mix, and it accounted for $27 \%$ of the global energy consumption in 2018 (Fig. 1(a)) (BP, 2019). China remains to be the world's largest energy consumer, and it contributed $34 \%$ to the growth of the global energy demand in 2018 (Fig. 1(b)) (BP, 2019). In addition, coal is still China's dominant fuel. Its share of total energy consumption was $58 \%$ in 2018 (Fig. 2(a)). Fig. 2(b) shows the trend of coal consumption, which increased slightly in 2018 compared with the value in 2017 (BP, 2019).

Coal fly ash (CFA), a by-product of coal combustion, is one of the most abundant industrial solid wastes, and the emission of CFA increases annually. CFA contains heavy metals, polycyclic aromatic hydrocarbons, silica, and other toxic substances (Tanaka et al., 2008b; Pandey et al., 2011; Bartoňová, 2015). High CFA emissions can take over land resources, pollute the air, and damage human health (Delkash et al., 2015). Therefore, proper disposal of CFA is urgently required. At present, CFA is mainly used as building materials in the form of concrete (Dilmore and Neufeld, 2001), cement

\footnotetext{
* Corresponding author.

E-mail address: xgao@zju.edu.cn; xgao1@zju.edu.cn
}

(Bouzoubaa and Lachemi, 2001), and hollow blocks (Kumar, 2003) (Fig. 3). This material is also utilized in backfilling treatments (Yao et al., 2015). However, these applications have low utilization and low added value. Therefore, utilizing the advantages of CFA and transforming this material into a high-value-added product have become research hotspots. The main components of CFA are $\mathrm{Si}$ - and Al-containing compounds, which are similar to zeolite. Hence, CFA is conducive to the synthesis of zeolite (Cardoso et al., 2015).

Zeolite has broad application prospects due to its potential molecular sieving, high specific surface area, and good thermal and chemical stability (Wang et al., 2010; Jiang et al., 2011; Charkhi et al., 2012). Zeolite is a kind of aluminosilicate molecular sieve crystal with uniform pores, and its skeleton contains $\mathrm{Al}, \mathrm{Si}$, and $\mathrm{O}$ (Andaç et al., 2005). Cations and water exist in the pores (Vuong and Do, 2009). As depicted in Fig. 4, tetrahedral $\mathrm{TO}_{4}(\mathrm{~T}=\mathrm{Si}, \mathrm{Al})$ is the most basic structural unit of the zeolite framework, and interconnected tetrahedral $\mathrm{TO}_{4}$ requires additional cations to balance the negative charge generated by $\mathrm{Al}$ ions (Belviso, 2018).

The polyhedral rings that are formed by sharing $\mathrm{O}$ atoms and connected in different ways are called secondary building unit (SBU). Several common SBU are illustrated in Fig. 5. Composite building unit (CBU) is formed by the connection of SBU, and they form different kinds of zeolite skeleton structures through additional connections (Fig. 6) (Smith, 1988). Several common zeolite structures are illustrated in 


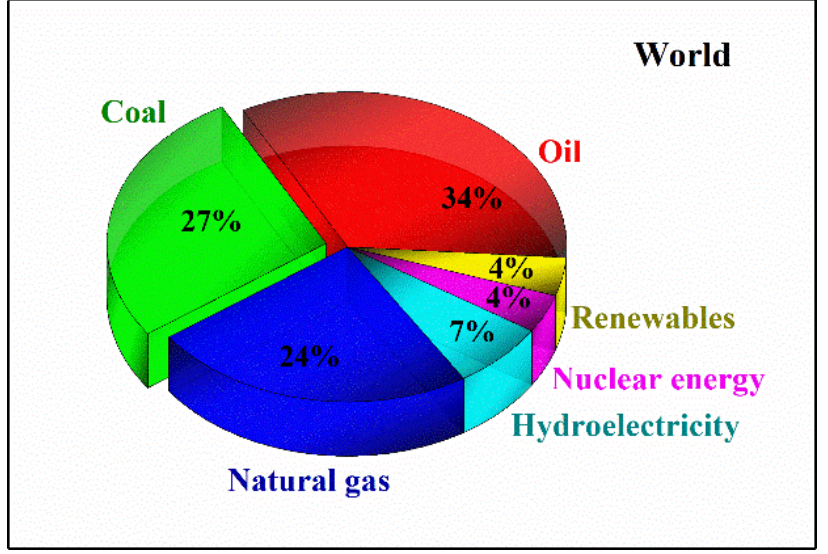

(a)

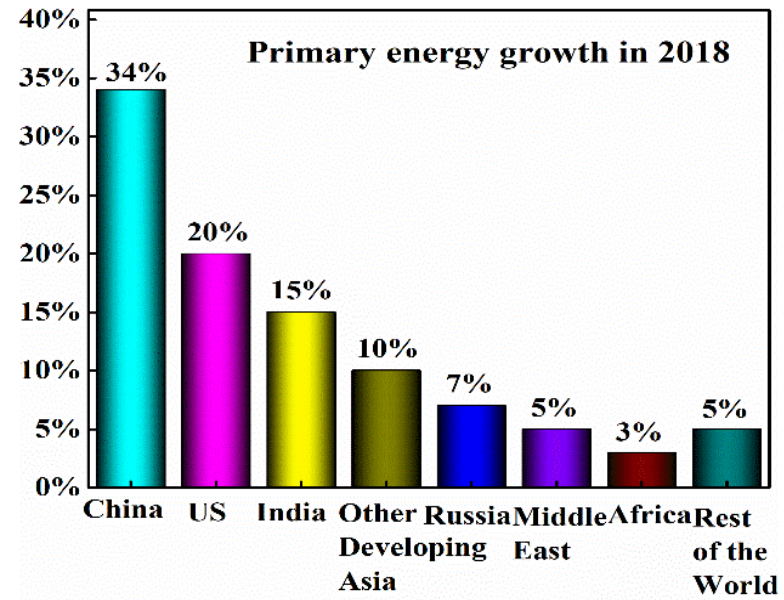

(b)

Fig. 1. (a) Shares of worldwide primary energy consumption and (b) contributions from different regions to primary energy growth in 2018.

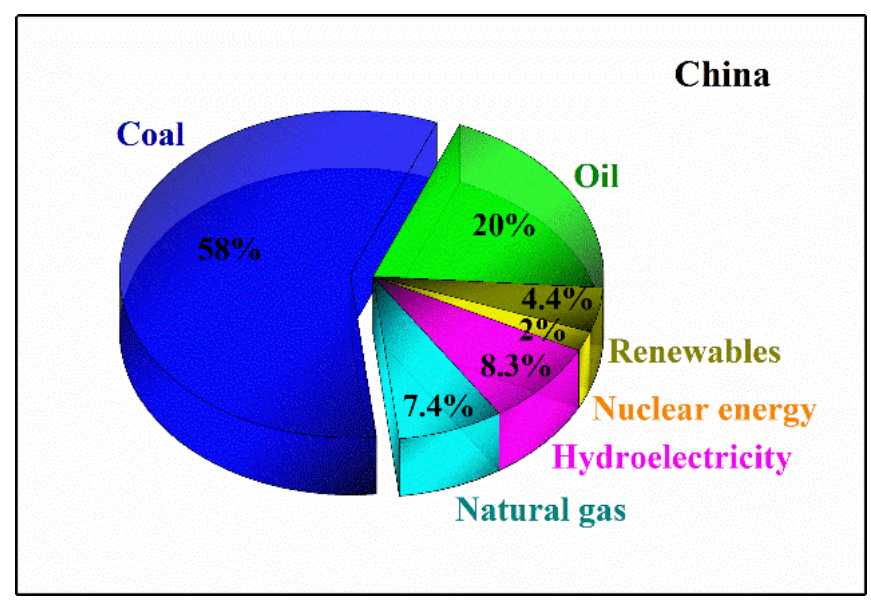

(a)

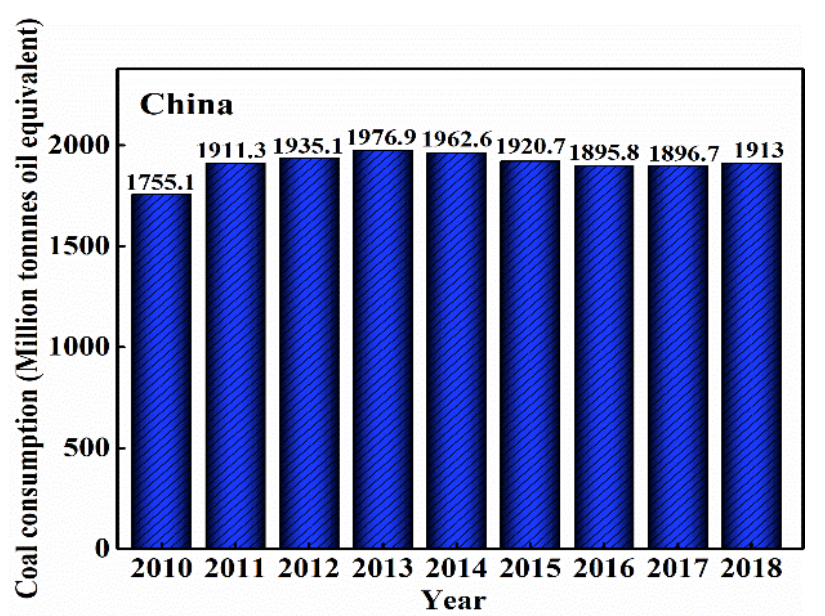

(b)

Fig. 2. (a) Shares of China primary energy consumption and (b) China's coal consumption in 2010-2018.

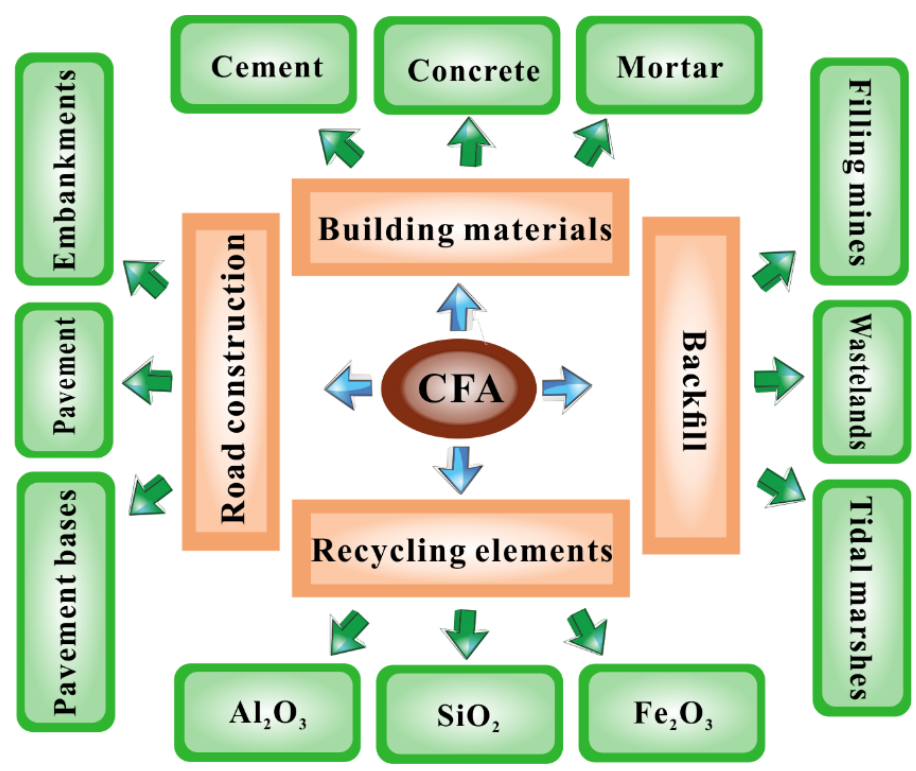

Fig. 3. Specific utilization of coal fly ash. 

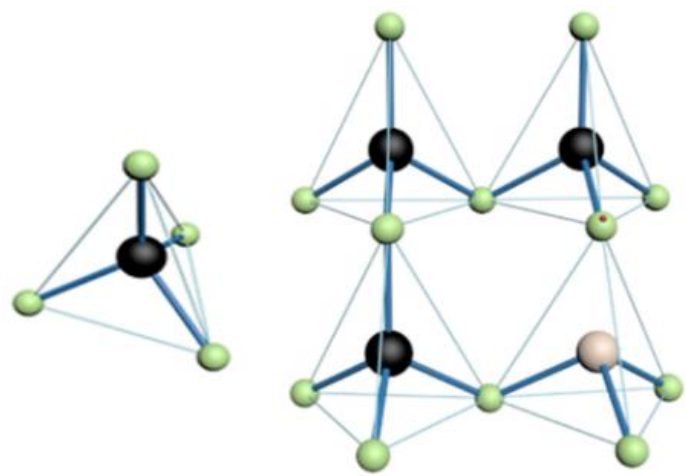

○ $\mathrm{Si}^{4+} \bigcirc \mathrm{Al}^{3+} \odot \mathbf{O}^{2-}$

Fig. 4. Aluminum replaces silicon in the tetrahedron to create a negative charge in the zeolite tetrahedral skeleton (adapted from Belviso, 2018).

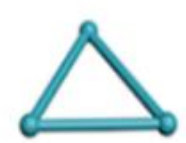

3

(1)

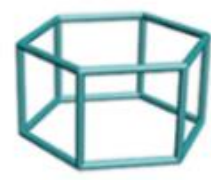

6-6

(10)

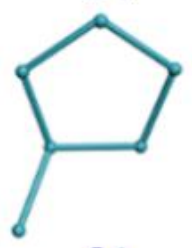

5-1

(14)

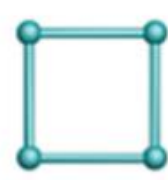

4

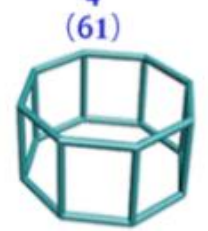

8-8

(3)

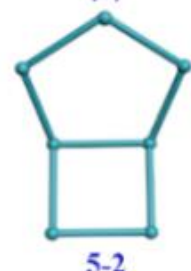

(4)

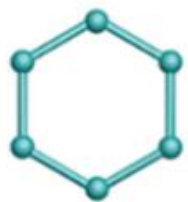

6

(39)

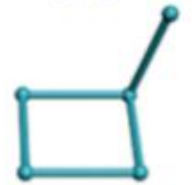

4-1

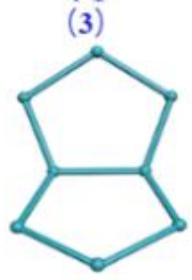

5-3

(8)

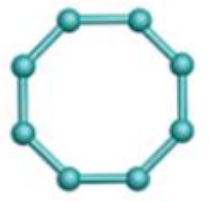

8

(15)

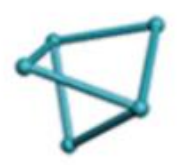

$4=1$

(3)

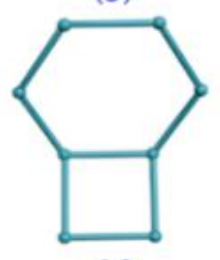

6-2

(21)

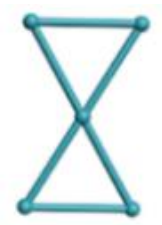

spiro-5

(1)

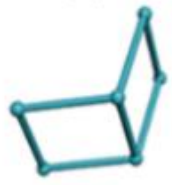

4-2

(9)

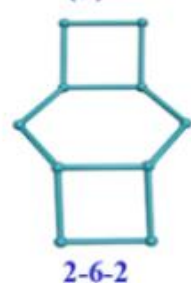

(3)

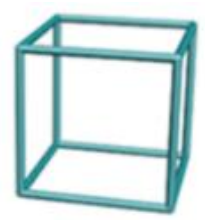

4-4

(6)

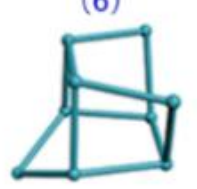

$4-4=1$

(2)

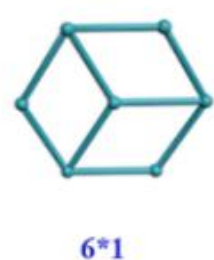

(2)

Fig. 5. Secondary building units and their symbols in framework structure of zeolite (adapted from Smith, 1988).

Fig. 7, and Table 1 presents their framework structures and related materials. Different zeolite structures result in distinct channels (Fig. 8). Benefitting from these structural features, zeolites have the characteristics of adsorption selectivity, high specific surface, and high ion exchange capacity (Hasan et al., 2012; Mousavi et al., 2013). Consequently, zeolites have enormous potential for adsorption and catalytic applications.

Sustained and rapid economic development and industrialization would inevitably increase the consumption of energy and other materials and could cause a series of environmental pollution problems, such as pollution by $\mathrm{SO}_{x}$ (Wang et al., 2018a; Carter et al., 2018; Yang et al., 2019b), $\mathrm{NO}_{x}$ (Gaskin et al., 2019), and volatile organic compounds (VOCs) (Aziz and Kim, 2017; Difallah et al., 2017; Wang et al., 2018b). Atmospheric aerosol is one of the main pollutants that affect the urban environment and human health, and it directly or indirectly causes haze, photochemical smog, acid rain, and other climate changes (Li et al., 2016). This pollutant contains many toxic and harmful substances and serves as a carrier of other pollutants, which cause great harm on human health and the ecological environment. Depending on the formation mechanism, atmospheric aerosols can be divided into primary and secondary aerosols (Seinfeld and Pankow, 2003). Primary aerosols refer to aerosol particles that are directly discharged into the atmosphere, and secondary aerosols are particles produced by the oxidation of certain gaseous pollutants (e.g., $\mathrm{SO}_{x}, \mathrm{NO}_{x}$, and hydrocarbons) in the atmosphere (e.g., from $\mathrm{SO}_{2}$ to $\mathrm{SO}_{4}{ }^{2-}$ ) (Pöschl, 2005).

Organic aerosols, most of which belong to secondary aerosols, account for 20-90\% of the aerosol mass concentration in terms of PM2.5 (particle size $\leq 2.5 \mathrm{~nm}$ ) (Riipinen et al., 2012). VOCs are important precursors for the formation of organic aerosols (Guenther et al., 2006). Therefore, reducing and controlling VOC emission are necessary. 


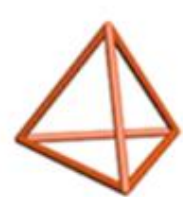

No.1

$3^{4}$

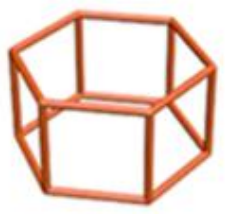

No.4

$4^{6} 6^{2}$

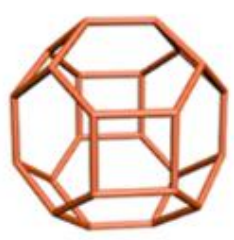

No.7

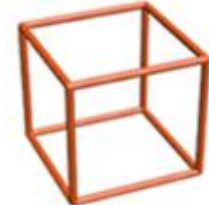

No.2

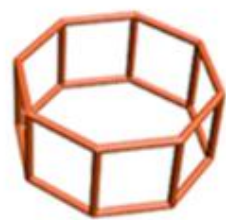

No.5

$4^{8} 8^{2}$

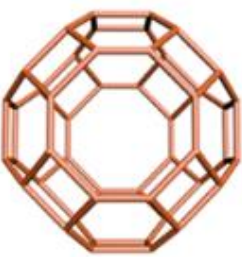

No. 8 $4^{12} 6^{8} 8^{6}$

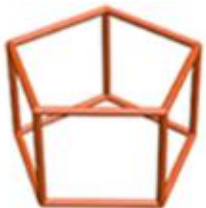

No.3 $4^{5} 5^{2}$
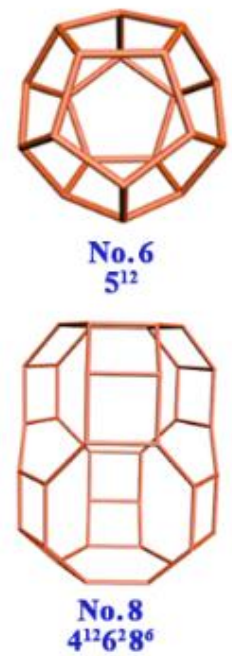

Fig. 6. Some common composite building units in framework structure of zeolite (adapted from Smith, 1988).

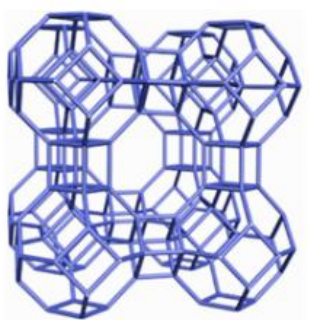

(a)

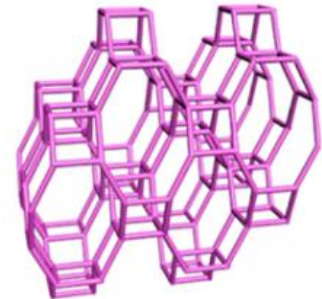

(d)

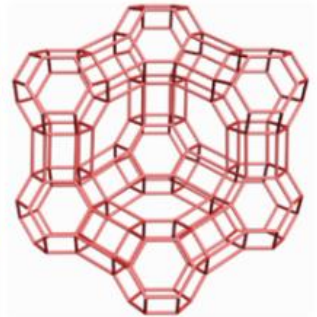

(b)

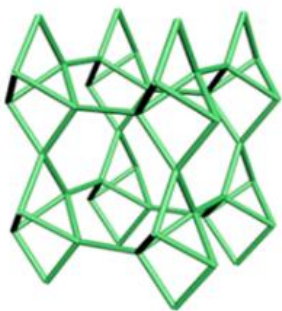

(e)

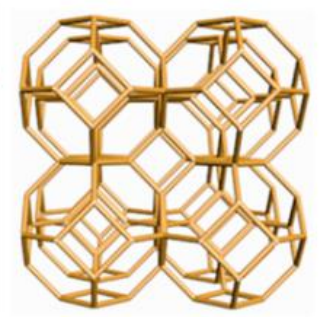

(c)

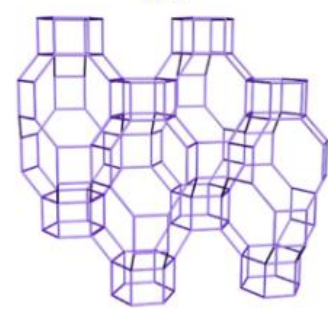

(f)

Fig. 7. Several common zeolite framework structures: (a) LTA (Yordanov et al., 2014), (b) FAU (Lim et al., 2009), (c) SOD (Leung et al., 2015), (d) GIS (Kunecki et al., 2018), (e) EDI (Harrison, 2001), (f) CHA (Smith et al., 2000).

Zeolites have been widely used for air pollution control due to their excellent performance. In recent years, the synthesis of zeolites with considerable properties (e.g., wide availability and low cost) from CFA has elicited much interest from researchers. Bukhari et al. (2015) introduced the progress of research on and the application of converting CFA into zeolites through microwave and ultrasonic energies. Mallapur and Oubagaranadin (2017) reviewed the progress of research on synthetic zeolites from fly ash, municipal solid waste, agricultural waste, industrial kaolin waste, and other hazardous inorganic waste. Belviso (2018) comprehensively analyzed the characteristics and application prospects of coal ash and biomass ash and discussed the key factors affecting the synthesis of zeolites from coal ash and the shortcomings of various synthetic methods. The present work reviews the synthesis methods of various zeolites from CFA and highlights the application progress of CFA-based zeolites in gas pollution control. 
Table 1. Several common zeolite framework structures and their related materials (from Structure Commission of the International Zeolite Association).

\begin{tabular}{|c|c|c|c|c|c|c|c|c|}
\hline \multirow{2}{*}{ Type } & \multirow{2}{*}{ Cell shape } & \multirow{2}{*}{ Channel } & \multicolumn{3}{|c|}{ Unit cell dimension } & \multirow{2}{*}{$\mathrm{CBU}$} & \multirow{2}{*}{ Related materials } & \multirow{2}{*}{ Ref. } \\
\hline & & & $a(\AA)$ & $\mathrm{b}(\AA)$ & $c(\AA)$ & & & \\
\hline LTA & Cubic & $3-\mathrm{D}$ & 4.21 & 4.21 & 4.21 & $\begin{array}{l}\text { d4r, sod, } \\
\text { lta }\end{array}$ & $\begin{array}{l}\text { Zeolite A, SAPO- } \\
42, \text { UZM-9, ITQ-29 }\end{array}$ & $\begin{array}{l}\text { (Lok et al., 1984; Corma } \\
\text { et al., 2004; Lewis et al., } \\
\text { 2004; Bouizi et al., 2007) }\end{array}$ \\
\hline FAU & Cubic & $3-\mathrm{D}$ & 7.35 & 7.35 & 7.35 & d6r, sod & $\begin{array}{l}\mathrm{NaX}, \mathrm{NaY}, \mathrm{ZSM}-20, \\
{[\mathrm{Ga}-\mathrm{Si}-\mathrm{O}]-\mathrm{FAU}}\end{array}$ & $\begin{array}{l}\text { (Newsam et al., 1989; } \\
\text { Occelli } \text { et al., 2000; } \\
\text { Greiser } \text { et al., 2016; } \\
\text { Schroeder } \text { et al., 2018) }\end{array}$ \\
\hline GIS & Tetragonal & $3-\mathrm{D}$ & 3.32 & 3.32 & 3.32 & gis & $\begin{array}{l}\mathrm{NaP} 1,[\mathrm{Be}-\mathrm{P}-\mathrm{O}]- \\
\text { GIS, SAPO- } 43 \text {, } \\
\text { garronite }\end{array}$ & $\begin{array}{l}\text { (Baerlocher and Meier, } \\
\text { 1972; Helliwell } \text { et al., } \\
\text { 1993; Artioli and Marchi, } \\
\text { 1999; Zhang et al., 2001) }\end{array}$ \\
\hline SOD & Cubic & 3-D & 2.53 & 2.53 & 2.53 & sod & $\begin{array}{l}\text { Sodalite, AIPO-20, } \\
\text { SIZ-9 }\end{array}$ & $\begin{array}{l}\text { Löns and Schulz, 1967; } \\
\text { Wilson et al., 1982; } \\
\text { Parnham and Morris, } \\
\text { 2006) }\end{array}$ \\
\hline EDI & Tetragonal & $3-\mathrm{D}$ & 3.2 & 3.2 & 3.44 & nat & $\begin{array}{l}\text { [Zn-As-O]-EDI, K- } \\
\text { F, Zeolite N, Linde } \\
\text { F }\end{array}$ & $\begin{array}{l}\text { (Tambuyzer and Bosmans, } \\
\text { 1976; Sherman, 1977; } \\
\text { Zeolite, 1997; Feng et al., } \\
\text { 2001) }\end{array}$ \\
\hline CHA & Trigonal & $3-\mathrm{D}$ & 3.72 & 3.72 & 3.72 & d6r, cha & $\begin{array}{l}\text { DAF-5, chabazite, } \\
\text { UiO-21, SSZ-62 }\end{array}$ & $\begin{array}{l}\text { (Sankar } \text { et al., 1998; } \\
\text { Kongshaug } \text { et al., 2000; } \\
\text { Zhang et al., 2008; } \\
\text { Itakura } \text { et al., 2011) }\end{array}$ \\
\hline
\end{tabular}

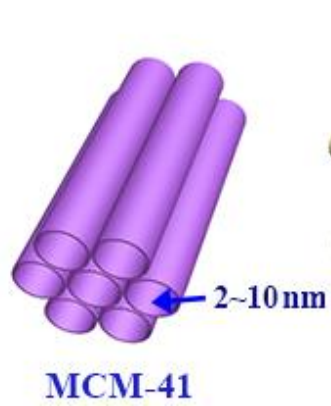

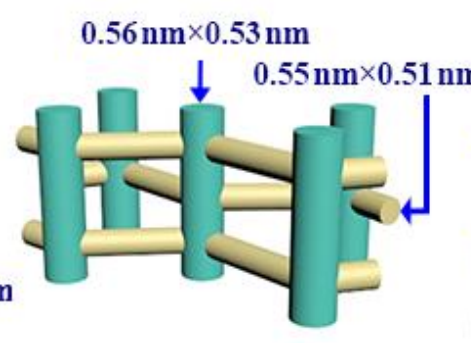

ZSM-5

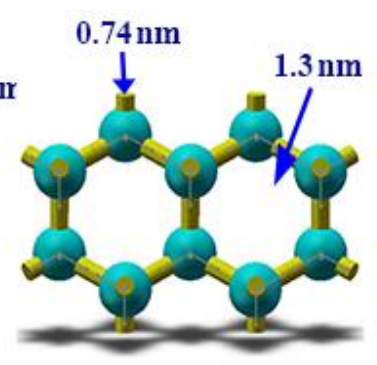

Faujasite

Fig. 8. Channel structure of (1) MCM-41 (Jabbari et al., 2015), (2) ZSM-5 (Flanigen et al., 1978), (3) faujasite (Johnson et al., 1999).

\section{SYNTHESIS OF ZEOLITES FROM CFA}

The research on and understanding of the crystallization mechanism of zeolites provide theoretical guiding significance for the synthesis of zeolites with specific structures and functions and have far-reaching importance for the process and technology of industrial production. Throughout the development history of zeolites, the discussion of their synthesis mechanism has consistently been a controversial topic. The formation of zeolites is a complicated process that involves the transformation of silicates and aluminates, the formation and dissolution of aluminosilicate, the continuous change in the gel's solid and solution phases, and the formation and growth of zeolite nucleation. On the basis of the changes in solid and liquid phases during synthesis, solid-phase, liquid-phase, and bidirectional transformation mechanisms have been proposed (Cundy and Cox, 2003). With the incessant progress of experimental and characterization methods, the understanding of the crystallization mechanism of zeolites has been constantly improved.

The principle of the solid-phase transformation mechanism is that no solid-phase dissolution should exist in the crystallization process, nor should the liquid phase be directly involved in the nucleation and crystal growth of zeolites. Only the structural rearrangement of the aluminosilicate skeleton generated by the gel solid under certain conditions is involved, resulting in the nucleation and crystal growth of zeolites (Tsapatsis et al., 1996). Breck (1964) investigated the relationship between zeolite crystallization and time through X-ray diffraction. The crystallization process was divided into two stages, namely, induction and growth. The solid-phase transformation mechanism was comprehensively 
examined via electron microscope analysis. Guth and Caullet (1986) verified that in extreme cases where only a large number of amorphous gels is present, the liquid phase does not participate in the crystallization process. Instead, the gel is directly rearranged in situ to synthesize zeolites.

Kerr (1966) proposed the liquid-phase transformation mechanism of zeolite crystallization. They found that the gel was initially dissolved in $\mathrm{NaOH}$ solution and produced dissolving derivatives, which in turn yielded the zeolite in the solution. The liquid-phase transformation mechanism also considers an equilibrium state between the solid and liquid phases. The growth of the crystal nucleus consumes the silicate and aluminate ions in the solution, and the consumption of the liquid-phase components in the crystallization process leads to the continued dissolution of the solid phase (Grizzetti and Artioli, 2002).

Improvements in characterization methods gave way to the development of the bidirectional transformation mechanism. Gabelica et al. (1984) studied the crystallization process of ZSM-5 through a dual system and found that the crystallization process of one system has many similarities with the liquidphase mechanism, whereas the other high-silicon system belongs to the solid-phase mechanism. Using the small-angle neutron scattering technique, Iton et al. (1992) confirmed that the crystallization mechanism of ZSM-5 varies with different silicon sources. Van Grieken et al. (2000) reported that the crystallization process of ZSM-5 zeolite is due to the simultaneous existence of solid- and liquid-phase mechanisms.

Theoretically, given that the main components of CFA are $\mathrm{Si}$ and $\mathrm{Al}$, zeolite can be synthesized from CFA. Many domestic and foreign scholars have conducted studies on this field (Yaping et al., 2008). The synthesis methods for zeolite include direct hydrothermal, two-step hydrothermal, alkaline fusion-assisted hydrothermal, and microwaveassisted methods. This section focuses on the analysis of the process and parameters of each method for the formation of zeolite types from CFA and the advantages and limitations of each approach. Fig. 9 displays the preparation process of zeolites with CFA as the raw material, and Table 2 shows information on the preparation methods and their products.

\section{Direct Hydrothermal Method}

The direct hydrothermal method involves dissolving CFA in an alkaline solution and subsequently synthesizing zeolite products through thermal treatment. Querol et al. (1999) investigated the influence of 14 kinds of Spanish CFA with different physical and chemical properties on zeolite synthesis. The results showed that CFA with the highest content of aluminum-silicate glass has the greatest potential for industrial application. The researchers also noted that in the process of synthesizing zeolites from CFA, the main active substances are glass and quartz, whereas mullite has low activity (Querol et al., 1995). Izidoro et al. (2012) discussed the synthesis of zeolites from five kinds of Brazilian CFA using the hydrothermal method and discovered that zeolite made from CFA containing more than $70 \% \mathrm{SiO}_{2}$ and $\mathrm{Al}_{2} \mathrm{O}_{3}$ has a high ion exchange capacity. The results also suggest that the element composition of CFA is one of the important factors that influence the synthesis of zeolites. Inada et al. (2005a) analyzed the effect of the $\mathrm{Si} / \mathrm{Al}$ molar ratio and alkaline condition on the type of synthetic zeolite. The authors showed that it is beneficial to the formation of Zeolite $\mathrm{P}$ with silica-rich CFA at a low alkali concentration, whereas the addition of a Si source can promote the formation of Zeolite $\mathrm{P}$ at a high alkali concentration. This finding indicates that the addition of $\mathrm{Si}$ or $\mathrm{Al}$ sources can control the type of

\section{Synthetic methods}

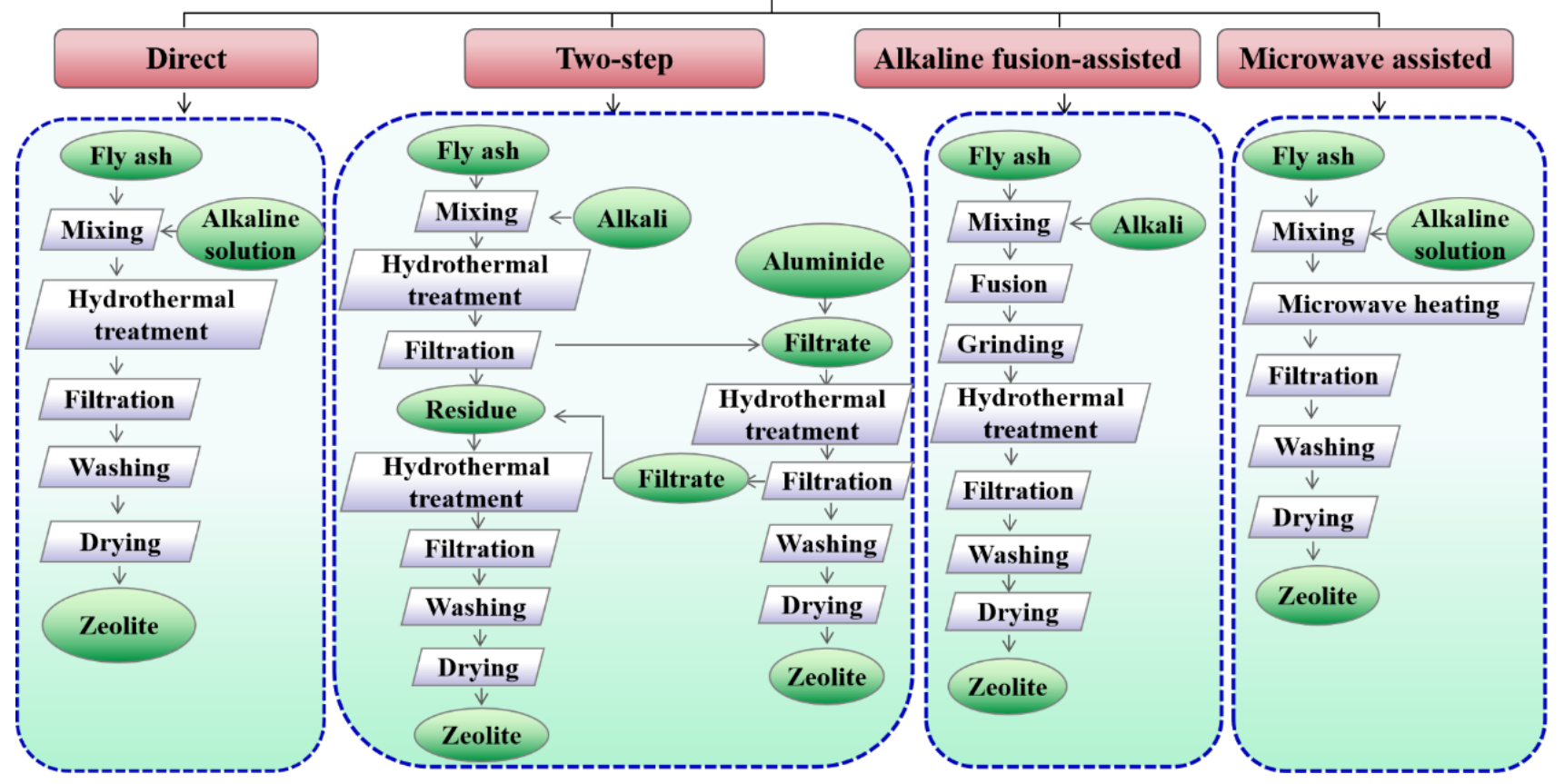

Fig. 9. Several typical flowcharts of preparation of zeolites from coal fly ash. 


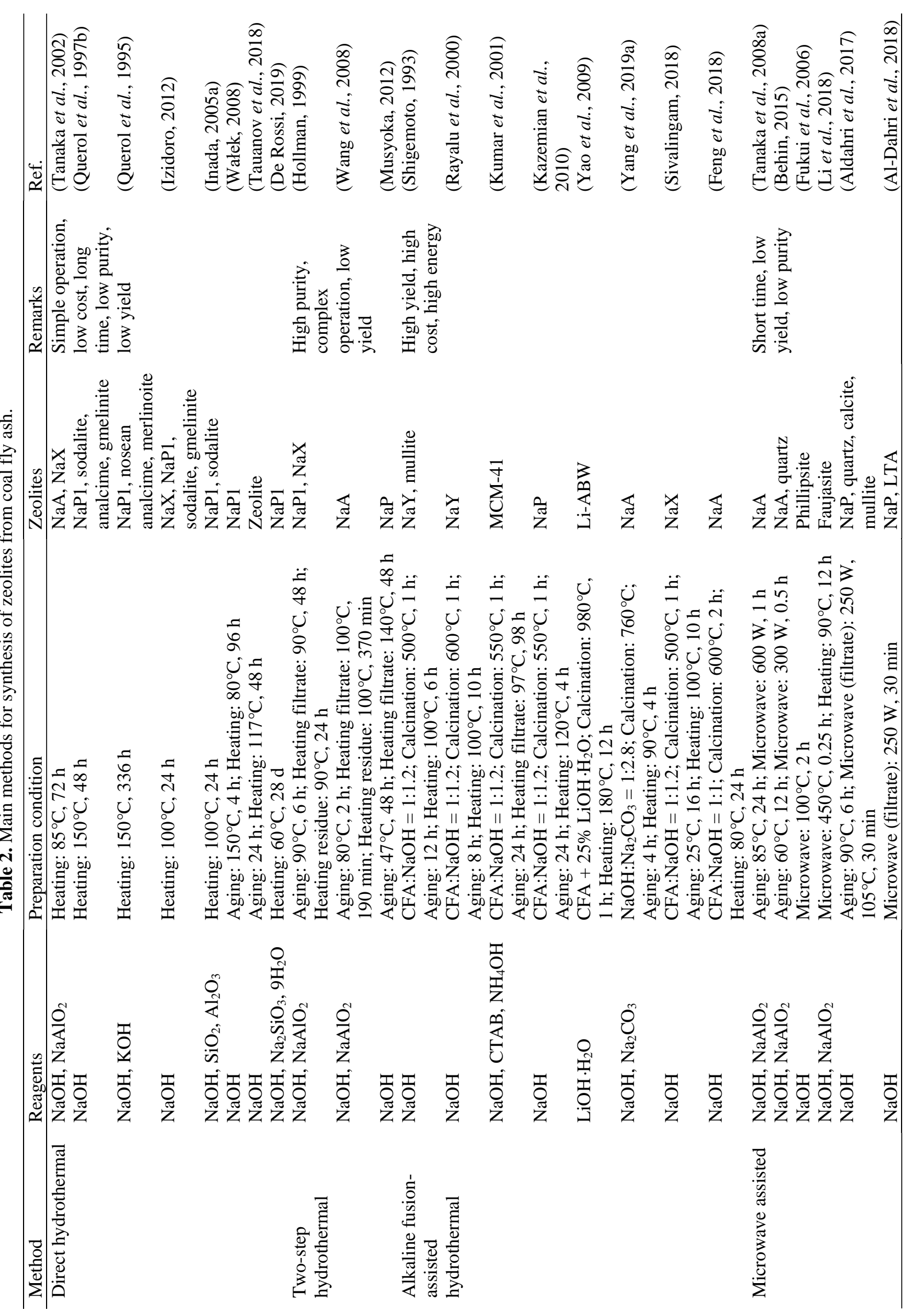


synthetic zeolites. Wałek et al. (2008) studied the influence of different solid/liquid $(\mathrm{S} / \mathrm{L})$ ratios on the synthesis of zeolites from CFA. They discovered that a low $\mathrm{S} / \mathrm{L}$ ratio is favorable to the dissolution of CFA. A single-phase NaP1 zeolite was obtained at conditions of $2 \mathrm{M} \mathrm{NaOH}$ solution, $104^{\circ} \mathrm{C}$ solution temperature, and $80^{\circ} \mathrm{C}$ crystallization temperature. The relationship between the synthesis conditions and the products was clearly described at a low $\mathrm{S} / \mathrm{L}$ ratio. The $\mathrm{S} / \mathrm{L}$ ratio usually used is $50-150 \mathrm{~g} \mathrm{dm}^{-3}$, which greatly limits the dissolution of CFA. But the low $\mathrm{S} / \mathrm{L}$ ratio $\left(4 \mathrm{~g} \mathrm{dm}^{-3}\right)$ reached $85 \mathrm{wt} \%$ in 4 hours. Murayama et al. (2002) described the effect of alkali on the mechanism for the synthesis of fly ashbased zeolites. They discovered that the $\mathrm{OH}^{-}$in the alkaline solution greatly promotes the dissolution of $\mathrm{Si}$ and $\mathrm{Al}$ ions, and $\mathrm{Na}$ ions promote the formation of Zeolite $\mathrm{P}$, which can selectively capture $\mathrm{K}^{+}$. Using biomass fly ash as the raw material, De Rossi et al. (2019) synthesized Zeolite P with a specific surface area of $56.35 \mathrm{~m}^{2} \mathrm{~g}^{-1}$ through an in situ method at $60^{\circ} \mathrm{C}$.

The direct hydrothermal method has a simple operation and low production cost. However, the method still has several disadvantages, including long hydrothermal time, high temperature, high energy consumption, low product purity, low yield, and many by-products.

\section{Two-step Hydrothermal Method}

Hollman et al. (1999) were the first to extend the one-step method to two-step synthesis of pure zeolites from CFA. The $\mathrm{Si}$ in CFA can be extracted by adding $\mathrm{NaOH}$ solution to synthesize pure zeolite (> 99\%). In addition, the solid residue from the reaction can be converted into zeolite via the traditional method. The cationic exchange capacity of pure zeolite is approximately two times that of the blend zeolite/ residual CFA, which renders the former more suitable for wastewater treatment than the latter. Moriyama et al. (2005) described the effect of high-temperature processing and drainage during operation on the synthesis of zeolites from CFA. They found that the appropriate synthesis condition involves $2.5-3.5 \mathrm{~mol} \mathrm{~L}^{-1}$ of $\mathrm{NaOH}$ and $0.88-1.10 \mathrm{~L} \mathrm{~kg}^{-1}$ of liquid/solid. The zeolite obtained by a pilot plant has a higher cation exchange capacity than that produced by the traditional method. Wang et al. (2008) discussed the effects of $\mathrm{NaOH}$ concentration on the dissolution of silica in CFA and synthesized different types of zeolites through the twostep method. The findings revealed that due to the increase in $\mathrm{NaOH}$ concentration, Zeolite A with a narrow particle size distribution can be obtained within a short crystallization time. Submicron Zeolite A was synthesized from CFA for the first time. Musyoka et al. (2012) optimized the synthesis parameters of pure-phase Zeolite $\mathrm{P}$ synthesized from three kinds of CFA by using the two-step method. They reported that the quality of synthetic zeolites is largely affected by the CFA source and can be improved by adjusting the experimental conditions. Moreover, the cation exchange capacity of purephase Zeolite $\mathrm{P}$ can reach $4.11 \mathrm{meg} \mathrm{g}^{-1}$.

The $\mathrm{Si}$ and $\mathrm{Al}$ ions in the waste liquor of the direct hydrothermal synthesis process can be fully utilized in the two-step synthesis process. Zeolites with high purity can be further obtained by adding a Si or Al source. However, this method entails a complex operation, long reaction cycle, low yield of pure zeolite, and high cost.

\section{Alkaline Fusion-assisted Hydrothermal Method}

The alkaline fusion-assisted hydrothermal method was introduced to improve the yield and quality of zeolite synthesis. This method comprises two main parts. The first part involves melting the mixture of CFA and alkali at a high temperature. In the second part, the alkali melt product is processed through hydrothermal treatment.

Shigemoto et al. (1993) were the first to introduce the alkaline fusion-assisted hydrothermal process for the synthesis of Zeolite X with a crystallinity of $62 \%$. Mullite was proven to be an inert substance that limits the quality and yield of zeolite synthesized from CFA. The mechanism of this method was also analyzed by Berkgaut and Singer (1996), who proved that the formation of sodium aluminosilicates occurs through an endothermic reaction at $170-180^{\circ} \mathrm{C}$. Aluminosilicate gel can be formed and further converted into zeolite by mixing with water. The researchers also discovered that mullite can be fully hydrolyzed and converted into zeolite by adding a small amount of water to the mixture of $\mathrm{CFA}$ and $\mathrm{NaOH}$ before melting. Rayalu et al. (2000) analyzed the effects of $\mathrm{NaOH}$ concentration on the conversion of CFA and types of zeolites. They showed that a low $\mathrm{NaOH}$ concentration leads to a small extraction amount of aluminum silicate in CFA, which is not conducive to the formation of zeolite. However, excessive $\mathrm{NaOH}$ enrichment results in the conversion of zeolite to hydroxysodalite. Zeolites synthesized through the alkali fusion method usually have a higher specific surface area, cation exchange capacity, and crystallinity than those synthesized using the traditional hydrothermal method (Molina and Poole, 2004). Wajima and Sugawara (2010) reported that the amount of calcium in CFA has an important effect on the type of zeolite, and a low calcium content is conducive to the synthesis of zeolite. Yang et al. (2019a) proved that the synthesis of zeolite with the double alkali method is more effective than that with the single alkali approach. Using response surface methodology, Sivalingam and Sen (2018) synthesized Zeolite X with a maximum crystallinity of $76 \%$ and a maximum yield of $88 \%$. The crystal violet adsorption capacity is $99.62 \%$, which is better than that of commercial Zeolite X. Feng et al. (2018) quantified the transfer of heavy metals from fly ash to produce zeolite and wastewater and realized high conversion of the main elements $(98.2 \% \mathrm{Al}$ and $96.5 \% \mathrm{Si})$ to synthesize zeolite and zero secondary solid waste.

Many studies have proven that zeolites synthesized through the alkaline fusion-assisted hydrothermal method have high conversion and quality. This method can be successfully applied to different kinds of CFA, but it requires calcination, which increases the cost of preparation and needs further study.

\section{Microwave-assisted Method}

Querol et al. (1997a) proposed the synthesis of zeolites from CFA through the microwave-assisted method, which is a synthesis process that involves changing the heating mode from electric heating to microwave heating. Compared with 
the traditional hydrothermal method, the microwave method can obtain zeolites with the same quality but within a shorter time. Tanaka et al. (2008a) proved that the microwave method can shorten the crystallization time and obtained singlephase Zeolite A from CFA through this technique. Inada et al. (2005b) described the effect of microwave irradiation on the yield of zeolite synthesized from CFA and analyzed the crystallization mechanism of zeolite. They demonstrated that microwave irradiation can effectively improve zeolitization, continuous microwave radiation can inhibit the formation of zeolite crystals, and early microwave heating is beneficial to the formation of zeolite. Behin et al. (2015) conducted an experimental study on the microwave synthesis of Zeolite A. Zeolite Linde Type A with high crystallinity and adsorption capacity were synthesized from CFA and industrial wastewater within a short time (10-30 $\mathrm{min})$ at a relatively low-power microwave irradiation (100-300 W).

Related studies indicate that the major advantages of the microwave-assisted method include increasing the crystallization rate, shortening the crystallization time, and reducing production costs, all of which provide the possibility for the industrialized production of zeolites from CFA. However, due to disadvantages, such as low zeolite conversion rate, numerous by-products, and certain difficulties in amplification engineering equipment, this method has been investigated only at the laboratory scale. Further studies are necessary before applying this method at the industrial scale.

In addition to these usual methods, other techniques,
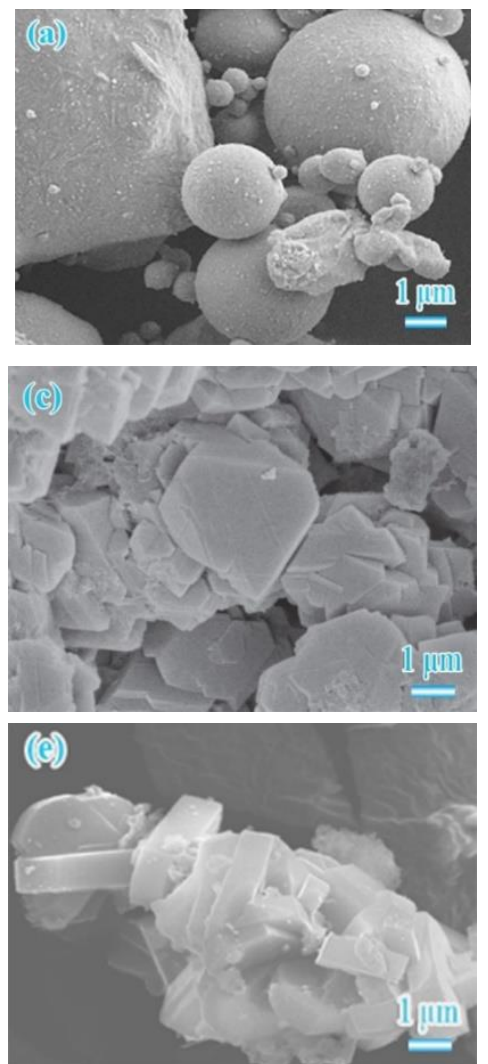

Fig. 10. SEM images of (a) coal fly ash (Missengue et al., 2017), (b) Zeolite A (Qian and Li, 2015), (c) Zeolite X (Hu et al., 2017), (d) Zeolite Y (Padhy et al., 2015), (e) Zeolite ZSM-5 (Anuwattana et al., 2008), (f) hydroxysodalite (Hong et al., 2017).
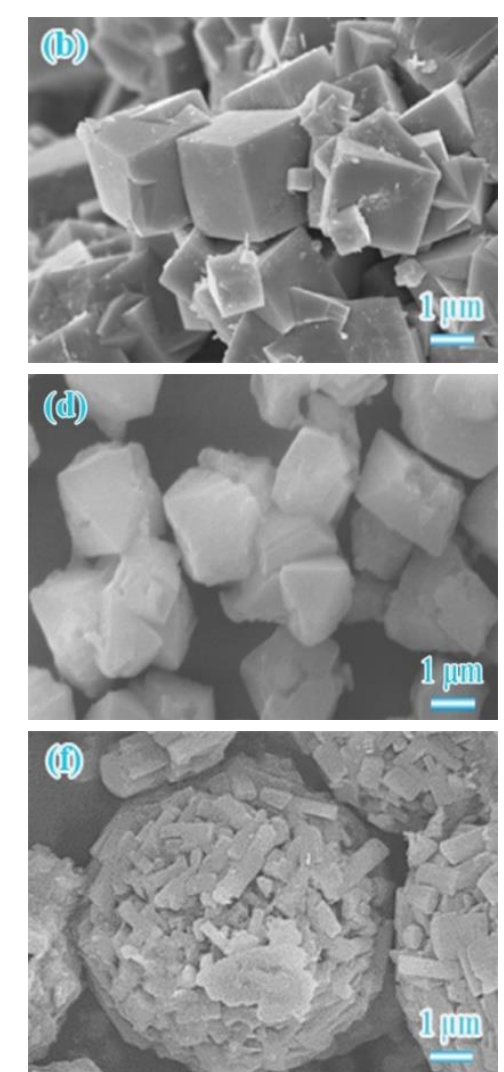

including molten salt method (Park et al., 2000; Choi et al., 2001), dialysis method (Tanaka et al., 2006), ultrasoundassisted method (Musyoka et al., 2011; Ojumu et al., 2016), and supercritical water technology (Jin et al., 2010), have also been used for the synthesis of zeolites from CFA. Different preparation methods and conditions can form different kinds of zeolites. Fig. 10 depicts the morphology of CFA and several typical zeolites obtained from CFA.

\section{APPLICATION OF CFA ZEOLITES FOR THE REMOVAL OF GASEOUS POLLUTANTS}

Air pollution due to $\mathrm{NO}_{x}$ (Zhang et al., 2019b), $\mathrm{CO}_{x}$ (Pillai et al., 2010; Younas et al., 2016; Zhang et al., 2017), $\mathrm{SO}_{2}$ (Zhang et al., 2019a), Hg (Qi et al., 2015), and VOCs (Lee et al., 2004; Bhatia et al., 2009; Cosseron et al., 2013) is detrimental to human beings and the environment. The main sources and hazards of these pollutants are listed in Table 3. Effectively controlling and reducing air pollution are important issues for scientists today.

At present, the common methods for treating gas pollutants include adsorption (Kang et al., 2018), biodegradation (Zhu et al., 2013), direct combustion (Pan et al., 2018), and catalytic oxidation (Saqer et al., 2011); adsorption and catalytic oxidation are considered the two most effective methods. The adsorption method is widely used due to its advantages, including simple equipment, easy operation, convenient economy, and high efficiency, and its mechanism has been widely studied. 
Table 3. Primary sources and effects of gaseous pollutants.

\begin{tabular}{|c|c|c|c|c|}
\hline \multicolumn{2}{|c|}{ Pollutants } & Primary sources & Environmental hazards & Ref. \\
\hline \multicolumn{2}{|l|}{$\mathrm{CO}_{2}$} & Fossil fuel combustion & Global warming, extreme weather & (Pillai et al., 2010; \\
\hline \multicolumn{2}{|l|}{$\mathrm{CO}$} & $\begin{array}{l}\text { Iron works, fertilizer plants } \\
\text { and petrochemical industry }\end{array}$ & $\begin{array}{l}\text { Harmful to the brain, cardiovascular } \\
\text { system and even fatal }\end{array}$ & $\begin{array}{l}\text { Younas et al., 2016; } \\
\text { Zhang et al., 2017) }\end{array}$ \\
\hline \multicolumn{2}{|l|}{$\mathrm{NO}_{x}$} & Fossil fuel combustion & Photochemical smog, acid rain & (Zhang et al., 2019b) \\
\hline \multicolumn{2}{|l|}{$\mathrm{SO}_{2}$} & Coal combustion & Acid rain, asthma & (Zhang et al., 2019a) \\
\hline \multicolumn{2}{|l|}{$\mathrm{Hg}$} & $\begin{array}{l}\text { Volcanic activity, fossil fuel } \\
\text { combustion }\end{array}$ & $\begin{array}{l}\text { Air and water pollution, insanity, } \\
\text { pneumonia }\end{array}$ & (Qi et al., 2015) \\
\hline \multirow[t]{6}{*}{ VOCs } & $\begin{array}{l}\text { Benzene } \\
\text { Toluene } \\
\text { Ethylbenzene }\end{array}$ & $\begin{array}{l}\text { Petroleum, adhesives, } \\
\text { lacquers, pesticides, } \\
\text { gasoline, paints, combustion } \\
\text { sources }\end{array}$ & $\begin{array}{l}\text { Carcinogen, damage the ozone layer, } \\
\text { photochemical smog }\end{array}$ & $\begin{array}{l}\text { (Lee } \text { et al., 2004; } \\
\text { Bhatia } \text { et al., 2009; } \\
\text { Cosseron } \text { et al., } \\
\text { 2013) }\end{array}$ \\
\hline & $\begin{array}{l}\text { Carbon tetrachloride } \\
\text { Chlorobenzene }\end{array}$ & $\begin{array}{l}\text { Chemical extractants, paints, } \\
\text { adhesive, polymer syntheses }\end{array}$ & $\begin{array}{l}\text { Acute toxicity, greenhouse effect, } \\
\text { damage the ozone layer }\end{array}$ & \\
\hline & Acetone & $\begin{array}{l}\text { Varnishes, adhesives, paint } \\
\text { thinners }\end{array}$ & $\begin{array}{l}\text { Central nervous system depression, } \\
\text { headache, nausea }\end{array}$ & \\
\hline & Formaldehyde & $\begin{array}{l}\text { Decorative, cosmetics, } \\
\text { adhesives, biomass burning }\end{array}$ & $\begin{array}{l}\text { Nasal tumors, irritation of the throat, } \\
\text { eyes, and skin }\end{array}$ & \\
\hline & Methanol & Preservative & $\begin{array}{l}\text { Central nervous system depression, } \\
\text { irritation of the throat and eyes }\end{array}$ & \\
\hline & Methylene chloride & $\begin{array}{l}\text { Flooring materials, furniture, } \\
\text { fumigants, coatings and } \\
\text { paints }\end{array}$ & $\begin{array}{l}\text { Carcinogen, irritation of skin, harm } \\
\text { to liver and kidney }\end{array}$ & \\
\hline
\end{tabular}

Many achievements in the removal of gaseous pollutants have been obtained through the combination of the abovementioned methods and mechanisms. Table 4 presents a summary of the research results on removing gaseous pollutants using zeolites synthesized by CFA.

\section{Removal of $S$ Compounds}

$\mathrm{SO}_{2}$ and $\mathrm{SO}_{3}$ are the major components of acid rain, and they can form sub-micron acid particles that are absorbed by the human body (Yang and Zhang, 2011; Hui et al., 2015). Srinivasan and Grutzeck (1999) used Class F CFA as a raw material for the synthesis of zeolites and investigated the influencing factors of $\mathrm{SO}_{2}$ adsorption. The results showed that the amount of removed $\mathrm{SO}_{2}$ depends on the type of zeolite, degree of drying, and zeolite content. Regardless of the CFA source, the sample $\left(150^{\circ} \mathrm{C}\right)$ containing analcime and sodalite could adsorb 6-7 $\mathrm{mg} \mathrm{SO}_{2}$ per gram, whereas the sample containing $\mathrm{X}, \mathrm{Y}$, and Na-P1 had significantly low adsorption efficiency. Suchecki et al. (2004) proved that fly ash zeolite (FAZ) is an effective $\mathrm{SO}_{2}$ adsorbent and has a higher adsorption capacity than CFA (Fig. 8). In addition, thermal activation increases the $\mathrm{SO}_{2}$ adsorption capacity of FAZs by two to three times, reaching up to $38 \mathrm{mg} \mathrm{SO} 2$ per gram of zeolite.

Izquierdo et al. (2013) prepared Ca-exchanged Zeolite Y from CFA and performed corresponding $\mathrm{SO}_{2}$ adsorption experiments. They reported that the adsorption ability of $\mathrm{SO}_{2}$ is strongly associated with the presence or absence of water in the flue gas. In the presence of water, $\mathrm{H}_{2} \mathrm{SO}_{4}$ and $\mathrm{CaSO}_{4}$ are formed in the adsorption process, which seriously changes the structure of zeolite and reduces its activity. Czuma et al. (2016) investigated the effect of different CFAbased zeolites obtained by changing the melting reaction parameters on the adsorption capacity of $\mathrm{SO}_{2}$. The authors stated that the yield and type of zeolites can be influenced by the alkali/ash ratio, alkali melting temperature, and adsorption capacity of $\mathrm{SO}_{2}$. They also observed that the adsorption capacity decreases after the first cycle, whereas it remains approximately constant during the second and third cycles.

\section{Removal of $\mathrm{CO}_{2}$}

The rapid increase in the concentration of $\mathrm{CO}_{2}$ in the atmosphere has elicited people's concern about global climate change and $\mathrm{CO}_{2}$ emission reduction. Liu et al. (2011) used the alkaline fusion hydrothermal method to form Zeolite A and $\mathrm{A}+\mathrm{X}$ mixtures from CFA, which were then used in a $\mathrm{CO}_{2}$ adsorption test. Compared with Zeolite $\mathrm{X}$ synthesized at a high temperature of $90^{\circ} \mathrm{C}$, the two zeolites have better performance in capturing $\mathrm{CO}_{2}$ from flue gas and are more selective for $\mathrm{CO}_{2}$ than $\mathrm{N}_{2}$. Lee and Jo (2010) studied the adsorption behavior of $\mathrm{Ca}$ ion-exchanged $\mathrm{Na}-\mathrm{P} 1$ and $\mathrm{Na}-\mathrm{A}$ zeolites prepared from CFA at a low $\mathrm{CO}_{2}$ concentration. Their results indicated that the best $\mathrm{CO}_{2}$ adsorption can be mainly attributed to the electrostatic behavior of $\mathrm{Ca}$ ions and the enhancement of acid-base interactions. Soe et al. (2016) and Muvumbu (2015) emphasized that $\mathrm{Ca}$ ion-exchanged zeolites have excellent $\mathrm{CO}_{2}$ adsorbability. Sarmah et al. (2013) performed $\mathrm{CO}_{2}$ adsorption experiments on CFA-based zeolite modified by monoethanolamine/ $N, N$-dimethylaniline and diethylamine $/ N, N$-dimethylaniline, and the adsorption capacity reached 6.89 and $5.99 \mathrm{mmol} \mathrm{g}^{-1}$ respectively. In addition, the modified zeolite had a lower cost and higher adsorption efficiency than commercial zeolite. Kalvachev et al. (2016) investigated the influence of preparation conditions on the conversion of CFA into zeolite and $\mathrm{CO}_{2}$ adsorption. 


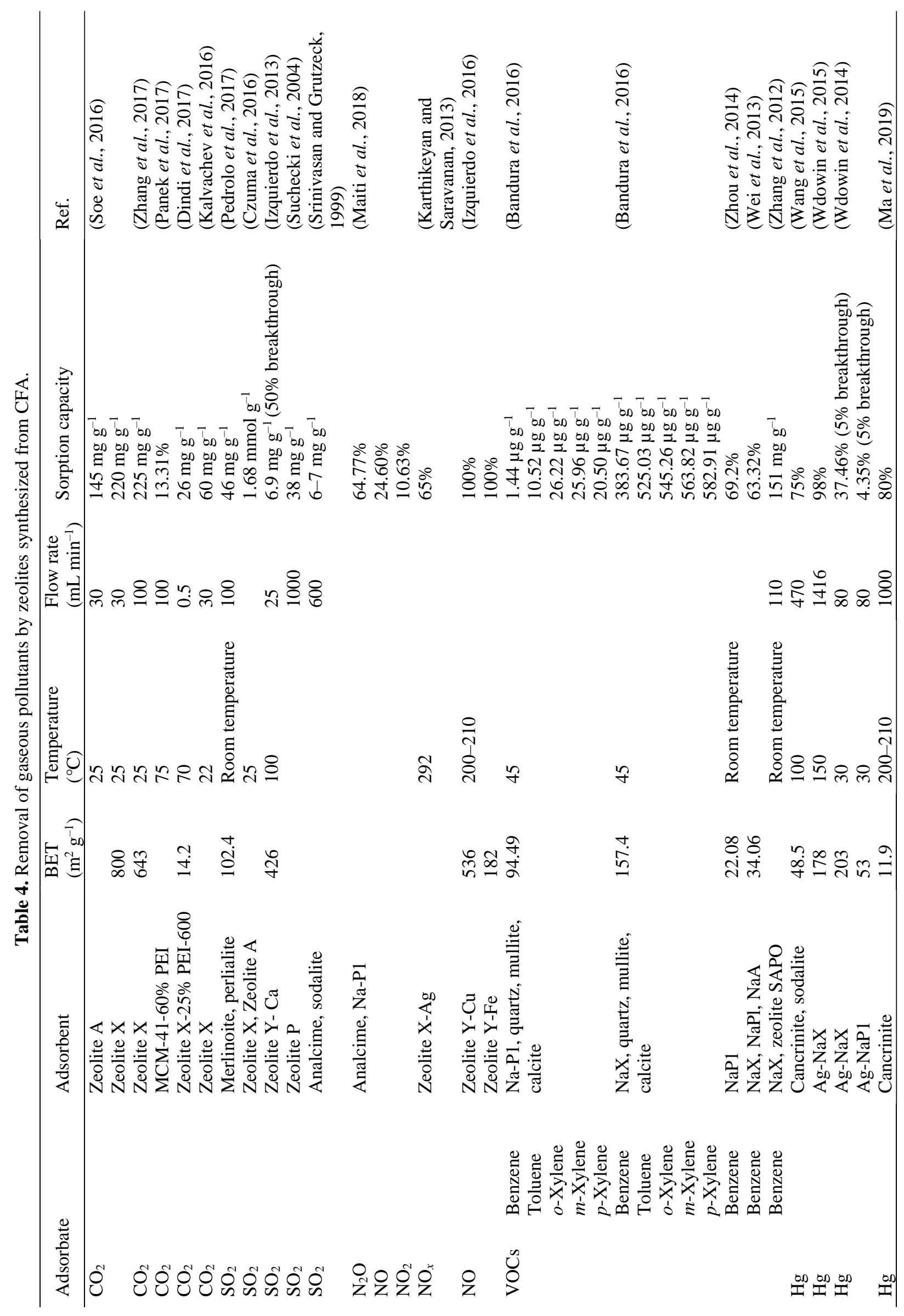


They reported that Zeolite $\mathrm{X}$ can be obtained when the alkali/ash ratio is 2 , the roasting temperature is $550^{\circ} \mathrm{C}$, and the hydrothermal reaction occurs at $90^{\circ} \mathrm{C}$ for $2 \mathrm{~h}$. The adsorption capacity of $\mathrm{CO}_{2}$ can reach $60 \mathrm{mg} \mathrm{g}^{-1}$ at $22^{\circ} \mathrm{C}$. Dindi et al. (2017) studied the effects of different polyethylenimine (PEI: MW-600 and MW-1200) loadings (15\%, 20\%, and $25 \%$ ) on $\mathrm{CO}_{2}$ adsorption. The results showed that PEI with a low molecular weight is better than that with a high molecular weight. The adsorption performance improves as the PEI load increases, but an excessive load hinders dispersion and degrades performance. At a loading of 25\%, PEI-600 achieves the maximum $\mathrm{CO}_{2}$ adsorption energy $\left(26 \mathrm{mg} \mathrm{g}^{-1}\right)$ at $70^{\circ} \mathrm{C}$.

\section{Removal of $N$ Compounds}

$\mathrm{NO}_{x}$ are common air contaminants that cause environmental issues, such as acid rain. López-Salinas et al. (1997) formed Zeolite P or faujasite-type zeolites from CFA and investigated the catalytic performance of $3.6 \mathrm{wt}$ \% $\mathrm{Cu}$-impregnated zeolites in the $\mathrm{CO}$ reduction of $\mathrm{NO}$. At $505 \mathrm{~K}$, the conversions of $\mathrm{NO}$ for $\mathrm{Cu}$-loaded Zeolite $\mathrm{P}$ and faujasite-type zeolite were $47 \%$ and $36 \%$, respectively, whereas the untreated CFA exhibited almost no activity in the reaction. Bopaiah and Grutzeck (2000) examined the synthesis of zeolites from CFA, ground glass particles, and cement kiln dust and their adsorption of $\mathrm{NO}_{2}$. The hydrothermal reaction was executed at $90^{\circ} \mathrm{C}$ for 56 days. The zeolite yield was about $30 \%$, and it was able to capture $88 \mathrm{mg}$ of $\mathrm{NO}_{2}$ per gram of zeolite. Karthikeya and Saravanan (2013) compared the catalytic removal of $\mathrm{NO}_{x}$ using ion-exchange CFA-based X-zeolite and commercial 13-X zeolite. The authors stated that the catalytic performance of $\mathrm{Ag}-\mathrm{X}, \mathrm{Fe}-\mathrm{X}$, and $\mathrm{Ni}-\mathrm{X}$ catalysts prepared from CFA is better than that of the commercial $13-\mathrm{X}$ zeolite catalyst. Furthermore, $\mathrm{Ag}$ and $\mathrm{Fe}$ zeolite catalysts have the best $\mathrm{NO}_{x}$ reduction performance at high and low temperatures, respectively, and no obvious deactivation occurs after $50 \mathrm{~h}$ of reaction. Izquierdo et al. (2016) investigated the selective catalytic reduction of $\mathrm{NO}$ with fly ash-derived Zeolite $\mathrm{Y}$ exchanged with $\mathrm{Cu}^{2+}$ or $\mathrm{Fe}^{2+}$. At temperatures below $200^{\circ} \mathrm{C}$ and in the presence of water, the difference in NO reduction is caused by the different temperatures of active substances $\mathrm{Cu}^{2+}$ and $\mathrm{Fe}^{3+}$ in the ion-exchanged zeolites and Zeolite LY$\mathrm{Cu}$ with a large surface area and high reactivity. The entire equation can be expressed as $4 \mathrm{NO}+4 \mathrm{NH}_{3}+\mathrm{O}_{2} \leftrightarrow 4 \mathrm{~N}_{2}+$ $6 \mathrm{H}_{2} \mathrm{O}$, where water is a product of the reaction. The presence of water vapor in the airflow can upset the equilibrium, increase the concentration of $\mathrm{NO}+\mathrm{O}_{2}$, further promote the oxidation of $\mathrm{Cu}^{+}$, and increase a large number of active sites because the oxidation of $\mathrm{Cu}^{+}$to $\mathrm{Cu}^{2+}$ below $325^{\circ} \mathrm{C}$ is due to $\mathrm{NO}+\mathrm{O}_{2}$. Maiti et al. (2018) applied X-ray photoelectron spectroscopy to examine the adsorption of harmful gaseous pollutants in CFA-based zeolite containing Na-P1 and analcime phases. Their findings revealed that synthetic zeolite has acid and thermal resistivity and can be used for internal and external environmental conditions. The highest adsorption of $\mathrm{N} 2 \mathrm{O}, \mathrm{NO}, \mathrm{CO}$, and $\mathrm{NO} 2$ on the zeolite surface reached $64.77 \%$, $24.60 \%, 12.94 \%$, and $10.63 \%$, respectively. Therefore, CFAbased zeolite could be used to purify the most common air contaminants in indoor and outdoor environments.

\section{Removal of Hg Vapor}

$\mathrm{Hg}$ is one of the most prominent pollutants in the environment due to its high volatility, high toxicity, and biological enrichment. Wdowin et al. (2014) investigated the adsorption of $\mathrm{Hg}$ from flue gases by activated carbon with bromine (AC/Br), a natural zeolite, and zeolites ( $\mathrm{Na}-\mathrm{X}$ and Na-P1) synthesized from CFA. The authors stated that untreated synthetic zeolite has almost no adsorption for $\mathrm{Hg}$. The $\mathrm{Hg}$ removal efficiency of $\mathrm{Na}-\mathrm{X} / \mathrm{Ag}$ obtained through the ion exchange method was higher than that obtained through the melting method and superior to $\mathrm{AC} / \mathrm{Br}$ and natural zeolite. The increased $\mathrm{Hg}$ adsorption efficiency of $\mathrm{Na}-\mathrm{X} / \mathrm{Ag}$ was attributed to the highest specific surface area of the zeolite treated with $\mathrm{Ag}$ and the highest combination of microporosity and medium porosity. In a subsequent study, Wdowin et al. (2015) indicated that the removal efficiency of $\mathrm{Hg}$ is related to the structure of the adsorbent (powder or particle), flue gas flow, contact time, and experimental temperature. According to the experimental results, Agimpregnated CFA-based Zeolite $\mathrm{X}$ reduces the $\mathrm{Hg}$ content in flue gas and obtains a long-term $\mathrm{Hg}$ breakthrough of 15$40 \%$. The effect of granular materials on $\mathrm{Hg}$ capture is preferable to that of powder materials. Wang et al. (2015) studied the adsorption performance of $\mathrm{Hg}$ by zeolite achieved from CFA by using the supercritical hydrothermal method. The CFA-based zeolite obtained at an S/L ratio of $15, \mathrm{NaOH}$ concentration of $1 \mathrm{~mol} \mathrm{~L}^{-1}$, supercritical water temperature of $400^{\circ} \mathrm{C}$, and reaction time of 5 min exhibited a satisfactory $\mathrm{Hg}$ removal performance. The authors emphasized that a low $\mathrm{Si} / \mathrm{Al}$ ratio and low $\mathrm{Ca}$ and $\mathrm{Fe}$ content are beneficial to the synthesis of zeolite. The sodalite and cancrinite in the product were the main active crystals, and at $100^{\circ} \mathrm{C}$ reaction for least $450 \mathrm{~min}$, the removal efficiency of $\mathrm{Hg}$ exceeded $75 \%$ and $60 \%$, respectively. Ma et al. (2019) used fly ash and Fe-containing waste as raw materials to synthesize magnetite through the one-step supercritical hydrothermal method. After modification using $\mathrm{HCl}$, the removal rate of the elemental $\mathrm{Hg}\left(\mathrm{Hg}^{0}\right)$ in the flue gas by zeolite exceeded $80 \%$ within the temperature range of $50-300^{\circ} \mathrm{C}$.

\section{Removal of VOCs}

VOCs have attracted increasing attention due to their contribution to the creation of photochemical smog and harmful effects on the atmosphere and human health. Zhang et al. (2012) reported the adsorption of benzene on CFAbased Zeolite X modified using $20 \mathrm{wt} \% \mathrm{HCl}$ and $10 \mathrm{M}$ $\mathrm{NaOH}$. During their tests, they observed that the maximum adsorption capacity of Zeolite $\mathrm{X}$ on benzene is $151 \mathrm{mg} \mathrm{g}^{-1}$, which is higher than that of commercial activated carbon. The results showed that the adsorption capacity is influenced by the preparation temperature and time. In a subsequent study, the researchers discovered that Zeolite $\mathrm{X}$ produced from CFA at a hydrothermal temperature of $140^{\circ} \mathrm{C}$ for $8 \mathrm{~h}$ has an Si/Al molar ratio of 7.9 and an adsorption rate of $66.51 \%$ on benzene gas (Wei et al., 2013). Zhou et al. (2014) generated CFA-based zeolite by alkali mixture $(\mathrm{NaOH}$ and $\mathrm{KOH})$ modification and used it for benzene vapor adsorption. The results showed that single-phase zeolite NaP1 can be obtained in the $8 \mathrm{M}$ mixed alkali solution, and the adsorption 
energy of benzene vapor can reach $69.2 \%$, which is similar to that of commercial benzene vapor adsorbents. Rayalu et al. (2006) utilized surface-modified Zeolite Y formed from CFA as an adsorbent for VOCs. Their results indicated that Zeolite Y modified by hexadecyltrimethylammonium bromide increases the hydrophobicity and adsorption capacity of VOCs. This material is stable at $250^{\circ} \mathrm{C}$, which is higher than the desorption temperature. In addition, the product has strong adsorption selectivity toward VOCs, good stability, and regeneration possibility. Bandura et al. (2016) demonstrated that $\mathrm{Na}-\mathrm{X}$ zeolite made from CFA has a higher adsorption capacity (383.67-582.91 $\mathrm{g} \mathrm{g} \mathrm{g}^{-1}$ ) for benzene, toluene, and xylene in flue gas compared with the CFA-based zeolite Na-P1 (1.44-20.50 $\left.\mu \mathrm{g} \mathrm{g}^{-1}\right)$, natural clinoptilolite $\left(0.68-2.84 \mu \mathrm{g} \mathrm{g}^{-1}\right)$, and diatomite $\left(0.20-0.96 \mu \mathrm{g} \mathrm{g}^{-1}\right)$. This was because micropores play a major role in the structure of faujasite with large-scale channels. The adsorption capacity of the experimental materials was in the order of xylene $>$ toluene $>$ benzene. Another study experimented on the use of synthetic zeolites from high-alumina CFA in the adsorption of formaldehyde, benzene, and toluene (Yuan et al., 2015). The products were amorphous silicate materials, crystalline calcite, and some impurities. In addition, the adsorption performance of the products on VOCs was similar to that of commercial activated carbon and stronger than that of commercial diatomite. The order of adsorption was toluene $>$ benzene $>$ formaldehyde. The Fourier transform infrared spectroscopy results indicated that a weak hydrogen bond interaction exists between the products and the three volatile organic compounds.

\section{CHALLENGES AND PERSPECTIVES}

Coal fly ash, the solid waste generated by coal-fired power plants, is one of the most innovative renewable energy sources. However, due to the annual increase in its cumulative emission, the resource utilization of CFA has become a serious issue. At present, the primary method of comprehensively utilizing this substance is to produce cement, concrete, and other building materials. However, numerous studies have emphasized that transforming CFA into zeolite products is an effective way to utilize and add high value to it. Our review summarizes the four major ways of synthesizing zeolites from CFA, namely, the direct hydrothermal, two-step hydrothermal, alkaline fusion-assisted hydrothermal, and microwave-assisted methods. Each method exhibits major advantages and disadvantages, so further research is required. Exploring novel synthetic methods or combining them with other techniques should also be considered. Because only a few types of zeolites can be synthesized currently from CFA, additional types should be developed and synthesized, and their purity, crystallinity, and conversion rates should be improved. Accelerating the industrialization of CFA-based zeolite synthesis is also an important research goal. Related literature suggests that the application of CFA-based zeolites in removing harmful gases mainly focuses on ion exchange and adsorption; Therefore, there is still much room for research on catalytic oxidation of these zeolites to remove harmful gases. Furthermore, research should be conducted to increase their efficiency in filtering exhaust gas and regenerating.

\section{ACKNOWLEDGEMENTS}

This work was financed by the National Science Foundation of China (51836006, No. U1609212) and Science \& Technology Project of Zhejiang Province (No. 2017C03007).

\section{REFERENCES}

Al-Dahri, T., AbdulRazak, A.A., Khalaf, I.H. and Rohani, S. (2018). Response surface modeling of the removal of methyl orange dye from its aqueous solution using two types of zeolite synthesized from coal fly ash. Mater. Express. 8: 234-244.

Aldahri, T., Behin, J., Kazemian, H. and Rohani, S. (2017). Effect of microwave irradiation on crystal growth of zeolitized coal fly ash with different solid/liquid ratios. Adv. Powder Technol. 28: 2865-2874.

Andaç, Ö., Tatlıer, M., Sirkecioğlu, A., Ece, I. and ErdemŞenatalar, A. (2005). Effects of ultrasound on zeolite A synthesis. Microporous Mesoporous Mater. 79: 225-233.

Anuwattana, R., Balkus Jr, K.J., Asavapisit, S. and Khummongkol, P. (2008). Conventional and microwave hydrothermal synthesis of zeolite ZSM-5 from the cupola slag. Microporous Mesoporous Mater. 111: 260-266.

Artioli, G. and Marchi, M. (1999). On the space group of garronite. Powder Diffr. 14: 190-194.

Aziz, A. and Kim, K.S. (2017). Adsorptive volatile organic removal from air onto NaZSM-5 and HZSM-5: Kinetic and equilibrium studies. Water Air Soil Pollut. 228: 319.

Baerlocher, C. and Meier, W. (1972). The crystal structure of synthetic zeolite Na-P1, an isotype of gismondine. $Z$. Kristallogr. Cryst. Mat. 135: 339-354.

Bandura, L., Panek, R., Rotko, M. and Franus, W. (2016). Synthetic zeolites from fly ash for an effective trapping of BTX in gas stream. Microporous Mesoporous Mater. 223: $1-9$.

Bartoňová, L. (2015). Unburned carbon from coal combustion ash: An overview. Fuel Process. Technol. 134: 136-158.

Behin, J., Bukhari, S.S., Dehnavi, V., Kazemian, H. and Rohani, S. (2015). Using coal fly ash and wastewater for microwave synthesis of LTA zeolite. Chem. Eng. Technol. 37: $1532-1540$.

Belviso, C. (2018). State-of-the-art applications of fly ash from coal and biomass: A focus on zeolite synthesis processes and issues. Prog. Energy Combust. Sci. 65: 109-135.

Berkgaut, V. and Singer, A. (1996). High capacity cation exchanger by hydrothermal zeolitization of coal fly ash. Appl. Clay Sci. 10: 369-378.

Bhatia, S., Abdullah, A.Z. and Wong, C.T. (2009). Adsorption of butyl acetate in air over silver-loaded $Y$ and ZSM-5 zeolites: Experimental and modelling studies. $J$. Hazard. Mater. 163: 73-81.

Bopaiah, S. and Grutzeck, M. (2000). Adsorption of $\mathrm{SO}_{\mathrm{x}}$ and $\mathrm{NO}_{\mathrm{x}}$ by zeolites synthesized from fly ash, cement kiln dust and recycled bottle glass. Abstr. Pap. Am. Chem. Soc. 220: U391-U391. 
Bouizi, Y., Paillaud, J.L., Simon, L. and Valtchev, V. (2007). Seeded synthesis of very high silica zeolite A. Chem. Mater. 19: 652-654.

Bouzoubaa, N. and Lachemi, M. (2001). Self-compacting concrete incorporating high volumes of class F fly ash: Preliminary results. Cem. Concr. Res. 31: 413-420.

Breck, D.W. (1964). Crystalline molecular sieves. J. Chem. Educ. 41: 678.

British Petroleum (BP) (2019). Statistical Review of World Energy 2019. BP Statistical Review of World Energy, UK.

Bukhari, S.S., Behin, J., Kazemian, H. and Rohani, S. (2015). Conversion of coal fly ash to zeolite utilizing microwave and ultrasound energies: A review. Fuel 140: 250-266.

Cardoso, A.M., Paprocki, A., Ferret, L.S., Azevedo, C.M. and Pires, M. (2015). Synthesis of zeolite Na-P1 under mild conditions using Brazilian coal fly ash and its application in wastewater treatment. Fuel 139: 59-67.

Carter, J.H., Han, X., Moreau, F.Y., da Silva, I., Nevin, A., Godfrey, H.G., Tang, C.C., Yang, S. and Schröder, M. (2018). Exceptional adsorption and binding of sulfur dioxide in a robust zirconium-based metal-organic framework. J. Am. Chem. Soc. 140: 15564-15567.

Charkhi, A., Kazemeini, M., Ahmadi, S.J. and Kazemian, H. (2012). Fabrication of granulated $\mathrm{NaY}$ zeolite nanoparticles using a new method and study the adsorption properties. Powder Technol. 231: 1-6.

Choi, C.L., Park, M., Lee, D.H., Kim, I.E., Park, B.Y. and Choi, J. (2001). Salt-thermal zeolitization of fly ash. Environ. Sci. Technol. 35: 2812-2816.

Corma, A., Rey, F., Rius, J., Sabater, M.J. and Valencia, S. (2004). Supramolecular self-assembled molecules as organic directing agent for synthesis of zeolites. Nature 431: 287-290.

Cosseron, A.F., Daou, T., Tzanis, L., Nouali, H., Deroche, I., Coasne, B. and Tchamber, V. (2013). Adsorption of volatile organic compounds in pure silica $\mathrm{CHA}, * \mathrm{BEA}$, MFI and STT-type zeolites. Microporous Mesoporous Mater. 173: 147-154.

Cundy, C.S. and Cox, P.A. (2003). The hydrothermal synthesis of zeolites: history and development from the earliest days to the present time. Chem. Rev. 103: 663-702.

Czuma, N., Zarębska, K. and Baran, P. (2016). Analysis of the influence of fusion synthesis parameters on the $\mathrm{SO}_{2}$ sorption properties of zeolites produced out of fly ash. E3S Web of Conferences, EDP Sciences, 10: 00010.

De Rossi, A., Simão, L., Ribeiro, M., Novais, R., Labrincha, J., Hotza, D. and Moreira, R. (2019). In-situ synthesis of zeolites by geopolymerization of biomass fly ash and metakaolin. Mater. Lett. 236: 644-648.

Delkash, M., Bakhshayesh, B.E. and Kazemian, H. (2015). Using zeolitic adsorbents to clean up special wastewater streams: A review. Microporous Mesoporous Mater. 214: 224-241.

Difallah, O., Hamaizi, H., Amate, M.D.U. and SociasViciana, M.D.M. (2017). Ordered silica particles made by nonionic surfactant for VOCs sorption. Mater. Res. 20: 1136-1142.
Dilmore, R.M. and Neufeld, R.D. (2001). Autoclaved aerated concrete produced with low $\mathrm{NO}_{\mathrm{x}}$ burner/selective catalytic reduction fly ash. J. Energy Eng. 127: 37-50.

Dindi, A., Quang, D.V., Nashef, E. and Zahra, M.R.A. (2017). Effect of PEI impregnation on the $\mathrm{CO}_{2}$ capture performance of activated fly ash. Energy Proc. 114: 2243-2251.

Feng, P., Zhang, T. and Bu, X. (2001). Arsenate zeolite analogues with 11 topological types. J. Am. Chem. Soc. 123: 8608-8609.

Feng, W., Wan, Z., Daniels, J., Li, Z., Xiao, G., Yu, J., Xu, D., Guo, H., Zhang, D. and May, E.F. (2018). Synthesis of high quality zeolites from coal fly ash: Mobility of hazardous elements and environmental applications. $J$. Cleaner Prod. 202: 390-400.

Flanigen, E.M., Bennett, J., Grose, R., Cohen, J., Patton, R., Kirchner, R. and Smith, J. (1978). Silicalite, a new hydrophobic crystalline silica molecular sieve. Nature 271: 512.

Fukui, K., Arai, K., Kanayama, K. and Yoshida, H. (2006). Phillipsite synthesis from fly ash prepared by hydrothermal treatment with microwave heating. Adv. Powder Technol. 17: 369-382.

Gabelica, Z., Derouane, E.G. and Blom, N. (1984). Factors Affecting the Synthesis of Pentasil Zeolites, In Catalytic Materials: Relationship between Structure and Reactivity, American Chemical Society, pp. 219-251.

Greiser, S., Hunger, M. and Jäger, C. (2016). ${ }^{29} \mathrm{Si}\left\{{ }^{27} \mathrm{Al}\right\}$ TRAPDOR MAS NMR to distinguish $\mathrm{Q}^{\mathrm{n}}(\mathrm{mAl})$ sites in aluminosilicates. Test case: Faujasite-type zeolites. Solid State Nucl. Magn. Reson. 79: 6-10.

Gaskin, S., Heath, L., Pisaniello, D., Logan, M. and Baxter, C. (2019). Skin permeation of oxides of nitrogen and sulfur from short-term exposure scenarios relevant to hazardous material incidents. Sci. Total Environ. 665: 937-943.

Grizzetti, R. and Artioli, G. (2002). Kinetics of nucleation and growth of zeolite LTA from clear solution by in situ and ex situ XRPD. Microporous Mesoporous Mater. 54: 105-112.

Guenther, A., Karl, T., Harley, P., Wiedinmyer, C., Palmer, P. and Geron, C. (2006). Estimates of global terrestrial isoprene emissions using MEGAN (Model of Emissions of Gases and Aerosols from Nature). Atmos. Chem. Phys. 6: 3181-3210.

Guth, J.L. and Caullet, P. (1986). Synthèse des zéolites. Perspectives d'avenir. J. Chim. Phys. 83: 155-175.

Harrison, W.T. (2001). $\left[\mathrm{H}_{3} \mathrm{~N}\left(\mathrm{CH}_{2}\right)_{3} \mathrm{NH}_{3}\right] 0.5\left[\mathrm{ZnPO}_{4}\right]$, an organically templated zincophosphate analogue of the aluminosilicate zeolite edingtonite. Acta Crystallogr., Sect. E 57: 248-250.

Hasan, F., Singh, R., Li, G., Zhao, D. and Webley, P.A. (2012). Direct synthesis of hierarchical LTA zeolite via a low crystallization and growth rate technique in presence of cetyltrimethylammonium bromide. J. Colloid Interface Sci. 382: 1-12.

Helliwell, M., Kaučič, V., Cheetham, G., Harding, M.M., Kariuki, B. and Rizkallah, P. (1993). Structure determination from small crystals of two aluminophosphates CrAPO-14 
and SAPO-43. Acta Crystallogr., Sect. B 49: 413-420.

Hollman, G., Steenbruggen, G. and Janssen-Jurkovičová, M. (1999). A two-step process for the synthesis of zeolites from coal fly ash. Fuel 78: 1225-1230.

Hong, J.L.X., Maneerung, T., Koh, S.N., Kawi, S. and Wang, C.H. (2017). Conversion of coal fly ash into zeolite materials: Synthesis and characterizations, process design, and its cost-benefit analysis. Ind. Eng. Chem. Res. 56: $11565-11574$.

Hu, T., Gao, W., Liu, X., Zhang, Y. and Meng, C. (2017). Synthesis of zeolites $\mathrm{Na}-\mathrm{A}$ and $\mathrm{Na}-\mathrm{X}$ from tablet compressed and calcinated coal fly ash. Roy. Soc. Open Sci. 4: 170921 .

Hui, Z., Bing, Z. and Bi, J. (2015). More efforts, more benefits: Air pollutant control of coal-fired power plants in China. Energy 80: 1-9.

Inada, M., Eguchi, Y., Enomoto, N. and Hojo, J. (2005a). Synthesis of zeolite from coal fly ashes with different silica-alumina composition. Fuel 84: 299-304.

Inada, M., Tsujimoto, H., Eguchi, Y., Enomoto, N. and Hojo, J. (2005b). Microwave-assisted zeolite synthesis from coal fly ash in hydrothermal process. Fuel 84: 1482 1486.

Itakura, M., Goto, I., Takahashi, A., Fujitani, T., Ide, Y., Sadakane, M. and Sano, T. (2011). Synthesis of highsilica CHA type zeolite by interzeolite conversion of FAU type zeolite in the presence of seed crystals. Microporous Mesoporous Mater. 144: 91-96.

Iton, L.E., Trouw, F., Brun, T., Epperson, J., White, J. and Henderson, S. (1992). Small-angle neutron-scattering studies of the template-mediated crystallization of ZSM5-type zeolite. Langmuir 8: 1045-1048.

Izidoro, J.d.C., Fungaro, D.A., dos Santos, F.S. and Wang, S. (2012). Characteristics of Brazilian coal fly ashes and their synthesized zeolites. Fuel Process. Technol. 97: 38-44.

Izquierdo, M.T., Juan, R. and Rubio, B. (2013). $\mathrm{SO}_{2}$ adsorption on type y zeolite synthesized from coal fly ash. Rev. Invest. Apl. 7: 11-19.

Izquierdo, M.T., Juan, R., Rubio, B. and Gómez-Giménez, C. (2016). No removal in the selective catalitic reduction process over $\mathrm{Cu}$ and $\mathrm{Fe}$ exchanged type $\mathrm{Y}$ zeolites synthesized from coal fly ash. Energy Sources Part A 38: 1183-1188.

Jabbari, A., Mahdavi, H., Nikoorazm, M. and GhorbaniChoghamarani, A. (2015). Salen copper (II) complex heterogenized on mesoporous MCM-41 as nano-reactor catalyst for the selective oxidation of sulfides using urea hydrogen peroxide (UHP). Res. Chem. Intermediat. 41: 5649-5663.

Jiang, N., Yang, G., Zhang, X., Wang, L., Shi, C. and Tsubaki, N. (2011). A novel silicalite-1 zeolite shell encapsulated iron-based catalyst for controlling synthesis of light alkenes from syngas. Catal. Commun. 12: 951954.

Jin, J., Li, X., Chi, Y. and Yan, J. (2010). Heavy metals stabilization in medical waste incinerator fly ash using alkaline assisted supercritical water technology. Waste Manage. Res. 28: 1133-1142.

Johnson, G.M., Lee, Y., Tripathi, A. and Parise, J.B. (1999).
Structural studies of hydrated germanium X-type zeolite via Rietveld analysis of synchrotron powder X-ray diffraction data. Microporous Mesoporous Mater. 31: 195-204.

Kalvachev, Y., Zgureva, D., Boycheva, S., Barbov, B. and Petrova, N. (2016). Synthesis of carbon dioxide adsorbents by zeolitization of fly ash. J. Therm. Anal. Calorim. 124: 101-106.

Kang, S., Ma, J., Wu, Q. and Deng, H. (2018). Adsorptive removal of dichloromethane vapor on FAU and MFI zeolites: Si/Al ratio effect and mechanism. J. Chem. Eng. Data 63: 2211-2218.

Karthikeya, D. and Saravanan, C. (2013). Experimental analysis of fly ash based, ion exchanged zeolite as catalyst for SI engine exhaust emission control. J. KONES 20: 229-235.

Karthikeyan, D. and Saravanan, C. (2013). Experimental analysis of fly ash based ion exchanged $\mathrm{Fe}, \mathrm{Cu}$ and $\mathrm{VX}$ zeolite catalysts for SI engine exhaust emission control. 2013 International Conference on Energy Efficient Technologies for Sustainability, Nagercoil, India, 10-12 April 2013, pp. 657-660.

Kazemian, H., Naghdali, Z., Kashani, T.G. and Farhadi, F. (2010). Conversion of high silicon fly ash to Na-P1 zeolite: Alkaline fusion followed by hydrothermal crystallization. Adv. Powder Technol. 21: 279-283.

Kerr, G.T. (1966). Chemistry of crystalline aluminosilicates. I. Factors affecting the formation of zeolite A. J. Phys. Chem. 70: 1047-1050.

Kongshaug, K.O., Fjellvåg, H. and Lillerud, K.P. (2000). The synthesis and crystal structure of two novel 3D openframework zinc phosphates UiO-21 and UiO-22. Microporous Mesoporous Mater. 39: 341-350.

Kumar, P., Mal, N., Oumi, Y., Yamana, K. and Sano, T. (2001). Mesoporous materials prepared using coal fly ash as the silicon and aluminium source. J. Mater. Chem. 11: 3285-3290.

Kumar, S. (2003). Fly ash-lime-phosphogypsum hollow blocks for walls and partitions. Build. Environ. 38: 291295.

Kunecki, P., Panek, R., Koteja, A. and Franus, W. (2018). Influence of the reaction time on the crystal structure of Na-P1 zeolite obtained from coal fly ash microspheres. Microporous Mesoporous Mater. 266: 102-108.

Lee, J.W., Shim, W.G. and Moon, H. (2004). Adsorption equilibrium and kinetics for capillary condensation of trichloroethylene on MCM-41 and MCM-48. Microporous Mesoporous Mater. 73: 109-119.

Lee, K.M. and Jo, Y.M. (2010). Synthesis of zeolite from waste fly ash for adsorption of $\mathrm{CO}_{2}$. J. Mater. Cycle. Waste Manage. 12: 212-219.

Leung, K.M., Edwards, P.P., Jones, E. and Sartbaeva, A. (2015). Microwave synthesis of LTN framework zeolite with no organic structure directing agents. RSC $A d v$. 5: 35580-35585.

Lewis, G., Miller, M., Moscoso, J., Wilson, B., Knight, L. and Wilson, S. (2004). Experimental charge density matching approach to zeolite synthesis. Stud. Surf. Sci. Catal. 154: 364-372. 
Li, J., Wang, G., Ren, Y., Wang, J., Wu, C., Han, Y., Zhang, L., Cheng, C. and Meng, J. (2016). Identification of chemical compositions and sources of atmospheric aerosols in Xi'an, inland China during two types of haze events. Sci. Total Environ. 566: 230-237.

Li, X.B., Ye, J.J., Liu, Z.H., Qiu, Y.Q., Li, L.J., Mao, S., Wang, X.C. and Zhang, Q. (2018). Microwave digestion and alkali fusion assisted hydrothermal synthesis of zeolite from coal fly ash for enhanced adsorption of Cd(II) in aqueous solution. J. Cent. South Univ. 25: 9-20.

Lim, W.T., Park, J.S., Lee, S.H., Jung, K.J. and Heo, N.H. (2009). Synthesis of tellurium sorption complexes in fully dehydrated and fully $\mathrm{Ca}^{2+}$-exchanged zeolites $\mathrm{A}$ and $\mathrm{X}$ and their single-crystal structures. Bull. Korean Chem. Soc. 30: 1274-1284.

Liu, L., Singh, R., Xiao, P., Webley, P.A. and Zhai, Y. (2011). Zeolite synthesis from waste fly ash and its application in $\mathrm{CO}_{2}$ capture from flue gas streams. Adsorption 17: 795-800.

Lok, B.M., Messina, C.A., Patton, R.L., Gajek, R.T., Cannan, T.R. and Flanigen, E.M. (1984). Silicoaluminophosphate molecular sieves: Another new class of microporous crystalline inorganic solids. J. Am. Chem. Soc. 106: 6092-6093.

Löns, J. and Schulz, H. (1967). Strukturverfeinerung von sodalith, $\mathrm{Na}_{8} \mathrm{Si}_{6} \mathrm{Al}_{6} \mathrm{O}_{24} \mathrm{Cl}_{2}$. Acta Crystallogr. 23: 434-436.

López-Salinas, E., Salas, P., Schifter, I., Morán, M., Castillo, S. and Mogica, E. (1997). Reduction of NO by $\mathrm{CO}$ using a zeolite catalyst obtained from fly ash. Stud. Surf. Sci. Catal. 105: 1565-1570.

Ma, L., Han, L., Chen, S., Hu, J., Chang, L., Bao, W. and Wang, J. (2019). Rapid synthesis of magnetic zeolite materials from fly ash and iron-containing wastes using supercritical water for elemental mercury removal from flue gas. Fuel Process. Technol. 189: 39-48.

Maiti, S., Raj, H., Bisht, R., Minocha, A., Panigrahi, S., Alexander, S. and Singh, M. (2018). X-ray photoelectron spectroscopy study on adsorption property of harmful air pollutants on zeolite prepared from fly ash. Mater. Res. Express 5: 085507.

Mallapur, V.P. and Oubagaranadin, J.U.K. (2017). A brief review on the synthesis of zeolites from hazardous wastes. Trans. Indian Ceram. Soc. 76: 1-13.

Missengue, R.N.M., Losch, P., Sedres, G., Musyoka, N.M., Fatoba, O.O., Louis, B., Pale, P. and Petrik, L.F. (2017). Transformation of South African coal fly ash into ZSM-5 zeolite and its application as an MTO catalyst. C.R. Chim. 20: 78-86.

Molina, A. and Poole, C. (2004). A comparative study using two methods to produce zeolites from fly ash. Miner. Eng. 17: 167-173.

Moriyama, R., Takeda, S., Onozaki, M., Katayama, Y., Shiota, K., Fukuda, T., Sugihara, H. and Tani, Y. (2005). Large-scale synthesis of artificial zeolite from coal fly ash with a small charge of alkaline solution. Fuel 84: 14551461.

Mousavi, S.F., Jafari, M., Kazemimoghadam, M. and Mohammadi, T. (2013). Template free crystallization of zeolite Rho via Hydrothermal synthesis: Effects of synthesis time, synthesis temperature, water content and alkalinity. Ceram. Int. 39: 7149-7158.

Murayama, N., Yamamoto, H. and Shibata, J. (2002). Mechanism of zeolite synthesis from coal fly ash by alkali hydrothermal reaction. Int. J. Miner. Process. 64: 1-17.

Musyoka, N., Petrik, L. and Hums, E. (2011). Ultrasonic assisted synthesis of zeolite A from coal fly ash using mine waters (acid mine drainage and circumneutral mine water) as a substitute for ultra pure water. Proceedings of International Mineral Water Association, Aachen, Germany, pp. 423-428.

Musyoka, N.M., Petrik, L.F., Gitari, W.M., Gillian, B. and Eric, H. (2012). Optimization of hydrothermal synthesis of pure phase zeolite Na-P1 from South African coal fly ashes. J. Environ. Sci. Health A 47: 337-350.

Muvumbu, J.L.M. (2015). Cation-exchanged zeolites-A prepared from South African fly ash feedstock for $\mathrm{CO}_{2}$ adsorption. [Master's thesis, University of the Western Cape]. https://etd.uwc.ac.za/xmlui/handle/11394/4699.

Newsam, J., Treacy, M., Vaughan, D., Strohmaier, K. and Mortier, W. (1989). The structure of zeolite ZSM-20: mixed cubic and hexagonal stackings of faujasite sheets. J. Chem. Soc., Chem. Commun. 8: 493-495.

Occelli, M., Schwering, G., Fild, C., Eckert, H., Auroux, A. and Iyer, P. (2000). Galliosilicate molecular sieves with the faujasite structure. Microporous Mesoporous Mater. 34: $15-22$.

Ojumu, T.V., Du Plessis, P.W. and Petrik, L.F. (2016). Synthesis of zeolite A from coal fly ash using ultrasonic treatment-A replacement for fusion step. Ultrason. Sonochem. 31: 342-349.

Padhy, R.R., Shaw, R., Tiwari, S. and Tiwari, S.K. (2015). Ultrafine nanocrystalline mesoporous $\mathrm{NaY}$ zeolites from fly ash and their suitability for eco-friendly corrosion protection. J. Porous Mater. 22: 1483-1494.

Pan, K.L., Pan, G.T., Chong, S. and Chang, M.B. (2018). Removal of VOCs from gas streams with double perovskite-type catalysts. J. Environ. Sci. 69: 205-216.

Pandey, V.C., Singh, J.S., Singh, R.P., Singh, N. and Yunus, M. (2011). Arsenic hazards in coal fly ash and its fate in Indian scenario. Resour. Conserv. Recycl. 55: 819-835.

Panek, R., Wdowin, M., Franus, W., Czarna, D., Stevens, L., Deng, H., Liu, J., Sun, C., Liu, H. and Snape, C.E. (2017). Fly ash-derived MCM-41 as a low-cost silica support for polyethyleneimine in post-combustion $\mathrm{CO}_{2}$ capture. $J$. $\mathrm{CO}_{2}$ Util. 22: 81-90.

Park, M., Choi, C.L., Lim, W.T., Kim, M.C., Choi, J. and Heo, N.H. (2000). Molten-salt method for the synthesis of zeolitic materials: I. Zeolite formation in alkaline moltensalt system. Microporous Mesoporous Mater. 37: 91-98.

Parnham, E.R. and Morris, R.E. (2006). The ionothermal synthesis of cobalt aluminophosphate zeolite frameworks. J. Am. Chem. Soc. 128: 2204-2205.

Pedrolo, D.R.S., de Menezes Quines, L.K., de Souza, G. and Marcilio, N.R. (2017). Synthesis of zeolites from Brazilian coal ash and its application in $\mathrm{SO}_{2}$ adsorption. J. Environ. Chem. Eng. 5: 4788-4794.

Pillai, R.S., Sethia, G. and Jasra, R.V. (2010). Sorption of $\mathrm{CO}, \mathrm{CH}_{4}$, and $\mathrm{N}_{2}$ in alkali metal ion exchanged zeolite-X: 
Grand canonical Monte Carlo simulation and volumetric measurements. Ind. Eng. Chem. Res. 49: 5816-5825.

Pöschl, U. (2005). Atmospheric aerosols: Composition, transformation, climate and health effects. Angew. Chem. Int. Ed. 44: 7520-7540.

Qi, H., Xu, W., Wang, J., Tong, L. and Zhu, T. (2015). $\mathrm{Hg}^{\mathrm{O}}$ removal from flue gas over different zeolites modified by $\mathrm{FeCl}_{3}$. J. Environ. Sci. 28: 110-117.

Qian, T. and Li, J. (2015). Synthesis of Na-A zeolite from coal gangue with the in-situ crystallization technique. Adv. Powder Technol. 26: 98-104.

Querol, X., Alastuey, A., Fernández-Turiel, J. and LópezSoler, A. (1995). Synthesis of zeolites by alkaline activation of ferro-aluminous fly ash. Fuel 74: 1226-1231.

Querol, X., Alastuey, A., López-Soler, A., Plana, F. Andrés, J.M., Juan, R., Ferrer, P. and Ruiz, C.R. (1997a). A fast method for recycling fly ash: Microwave-assisted zeolite synthesis. Environ. Sci. Technol. 31: 2527-2533.

Querol, X., Plana, F., Alastuey, A. and López-Soler, A. (1997b). Synthesis of Na-zeolites from fly ash. Fuel 76: 793-799.

Querol, X., Umana, J.C., Alastuey, A., Bertrana, C., LopezSoler, A. and Plana, F. (1999). Physicochemical characterization of spanish fly ashes. Energy Sources 21: 883-898.

Rayalu, S., Meshram, S. and Hasan, M. (2000). Highly crystalline faujasitic zeolites from flyash. J. Hazard. Mater. 77: 123-131.

Rayalu, S., Meshram, S., Biniwale, R.B., Srivasatava, A., Jadhav, P. and Devotta, S. (2006). Volatile organic carbon monitoring in indoor environment using a versatile hydrophobic flyash-based zeolite as adsorbent. Curr. Sci. 91: 497-503.

Riipinen, I., Yli-Juuti, T., Pierce, J.R., Petäjä, T., Worsnop, D.R., Kulmala, M. and Donahue, N.M. (2012). The contribution of organics to atmospheric nanoparticle growth. Nat. Geosci. 5: 453.

Sankar, G., Wyles, J.K., Thomas, J.M., Catlow, C.R.A., Lewis, D.W., Coles, S.J., Jones, R.H., Clegg, W. and Teat, S.J. (1998). Structure of templated microcrystalline DAF-5 $\uparrow\left(\mathrm{Co}_{0.28} \mathrm{Al}_{0.72} \quad \mathrm{PO}_{4} \mathrm{C}_{10} \mathrm{H}_{20} \mathrm{~N}_{2}\right)$ determined by synchrotron-based diffraction methods. Chem. Commun. 1: $117-118$.

Saqer, S.M., Kondarides, D.I. and Verykios, X.E. (2011). Catalytic oxidation of toluene over binary mixtures of copper, manganese and cerium oxides supported on $\gamma$ $\mathrm{Al}_{2} \mathrm{O}_{3}$. Appl. Catal. B 103: 275-286.

Sarmah, M., Baruah, B.P. and Khare, P. (2013). A comparison between $\mathrm{CO}_{2}$ capturing capacities of fly ash based composites of MEA/DMA and DEA/DMA. Fuel Process. Technol. 106: 490-497.

Schroeder, C., Hansen, M.R. and Koller, H. (2018). Ultrastabilization of zeolite $\mathrm{Y}$ transforms brønstedbrønsted acid pairs into brønsted-lewis acid pairs. Angew. Chem. Int. Ed. 57: 14281-14285.

Seinfeld, J.H. and Pankow, J.F. (2003). Organic atmospheric particulate material. Annu. Rev. Phys. Chem. 54: 121-140.

Sherman, J.D. (1977). Identification and characterization of zeolites synthesized in the $\mathrm{K}_{2} \mathrm{O}-\mathrm{Al}_{2} \mathrm{O}_{3}-\mathrm{SiO}_{2}-\mathrm{H}_{2} \mathrm{O}$ system.
In Molecular Sieves-II, American Chemical Society, Katzer, J.R. (Ed.), pp. 30-42.

Shigemoto, N., Hayashi, H. and Miyaura, K. (1993). Selective formation of $\mathrm{Na}-\mathrm{X}$ zeolite from coal fly ash by fusion with sodium hydroxide prior to hydrothermal reaction. J. Mater. Sci. 28: 4781-4786.

Sivalingam, S. and Sen, S. (2018). Optimization of synthesis parameters and characterization of coal fly ash derived microporous zeolite X. Appl. Surf. Sci. 455: 903-910.

Smith, J.V. (1988). Topochemistry of zeolites and related materials. 1. Topology and geometry. Chem. Rev. 88: 149-182.

Smith, L.J., Eckert, H. and Cheetham, A.K. (2000). Site preferences in the mixed cation zeolite, $\mathrm{Li}, \mathrm{Na}$-chabazite: A combined solid-state NMR and neutron diffraction study. J. Am. Chem. Soc. 122: 1700-1708.

Soe, J.T., Kim, S.S., Lee, Y.R., Ahn, J.W. and Ahn, W.S. (2016). $\mathrm{CO}_{2}$ capture and $\mathrm{Ca}^{2+}$ exchange using zeolite A and $13 \mathrm{X}$ prepared from power plant fly ash. Bull. Korean Chem. Soc. 37: 490-493.

Srinivasan, A. and Grutzeck, M.W. (1999). The adsorption of $\mathrm{SO}_{2}$ by zeolites synthesized from fly ash. Environ. Sci. Technol. 33: 1464-1469.

Suchecki, T., Walek, T. and Banasik, M. (2004). Fly ash zeolites as sulfur dioxide adsorbents. Pol. J. Environ. Stud. 13: 723-727.

Tambuyzer, E. and Bosmans, H. (1976). The crystal structure of synthetic zeolite K-F. Acta Crystallogr., Sect. B 32: 1714-1719.

Tanaka, H., Sakai, Y. and Hino, R. (2002). Formation of NaA and-X zeolites from waste solutions in conversion of coal fly ash to zeolites. Mater. Res. Bull. 37: 1873-1884.

Tanaka, H., Eguchi, H., Fujimoto, S. and Hino, R. (2006). Two-step process for synthesis of a single phase Na-A zeolite from coal fly ash by dialysis. Fuel 85: 1329-1334.

Tanaka, H., Fujii, A., Fujimoto, S. and Tanaka, Y. (2008a). Microwave-assisted two-step process for the synthesis of a single-phase Na-A zeolite from coal fly ash. $A d v$. Powder Technol. 19: 83-94.

Tanaka, H., Fujimoto, S., Fujii, A., Hino, R. and Kawazoe, T. (2008b). Microwave assisted two-step process for rapid synthesis of Na-A zeolite from coal fly ash. Ind. Eng. Chem. Res. 47: 226-230.

Tauanov, Z., Shah, D., Inglezakis, V. and Jamwal, P.K. (2018). Hydrothermal synthesis of zeolite production from coal fly ash: A heuristic approach and its optimization for system identification of conversion. $J$. Cleaner Prod. 182: 616-623.

Tsapatsis, M., Lovallo, M. and Davis, M.E. (1996). Highresolution electron microscopy study on the growth of zeolite L nanoclusters. Micropor. Mater. 5: 381-388.

Van Grieken, R., Sotelo, J., Menendez, J. and Melero, J. (2000). Anomalous crystallization mechanism in the synthesis of nanocrystalline ZSM-5. Microporous Mesoporous Mater. 39: 135-147.

Vuong, G.T. and Do, T.O. (2009). Synthesis of silylated nanozeolites in the presence of organic phase: Two-phase and single-phase methods. Microporous Mesoporous Mater. 120: 310-316. 
Wajima, T. and Sugawara, K. (2010). Material conversion from various incinerated ashes using alkali fusion method. Int. J. Soc. Mater. Eng. Resour. 17: 47-52.

Wałek, T.T., Saito, F. and Zhang, Q. (2008). The effect of low solid/liquid ratio on hydrothermal synthesis of zeolites from fly ash. Fuel 87: 3194-3199.

Wang, C.F., Li, J.S., Wang, L.J. and Sun, X.Y. (2008). Influence of $\mathrm{NaOH}$ concentrations on synthesis of pureform zeolite A from fly ash using two-stage method. $J$. Hazard. Mater. 155: 58-64.

Wang, H., You, C. and Tan, Z. (2018a). Enhanced photocatalytic oxidation of $\mathrm{SO}_{2}$ on $\mathrm{TiO}_{2}$ surface by $\mathrm{Na}_{2} \mathrm{CO}_{3}$ modification. Chem. Eng. J. 350: 89-99.

Wang, J., Li, D., Ju, F., Han, L., Chang, L. and Bao, W. (2015). Supercritical hydrothermal synthesis of zeolites from coal fly ash for mercury removal from coal derived gas. Fuel Process. Technol. 136: 96-105.

Wang, Y., Lei, Z., Chen, B., Guo, Q. and Liu, N. (2010). Adsorption of $\mathrm{NO}$ and $\mathrm{N}_{2} \mathrm{O}$ on Fe-BEA and H-BEA zeolites. Appl. Surf. Sci. 256: 4042-4047.

Wang, Y., Yang, D., Li, S., Chen, M., Guo, L. and Zhou, J. (2018b). Ru/hierarchical HZSM-5 zeolite as efficient bifunctional adsorbent/catalyst for bulky aromatic VOCs elimination. Microporous Mesoporous Mater. 258: 17-25.

Wdowin, M., Wiatros-Motyka, M.M., Panek, R., Stevens, L. A., Franus, W. and Snape, C.E. (2014). Experimental study of mercury removal from exhaust gases. Fuel 128: 451-457.

Wdowin, M., Macherzyński, M., Panek, R., Górecki, J., Franus, W. and Christidis, G. (2015). Investigation of the sorption of mercury vapour from exhaust gas by an Ag-X zeolite. Clay Miner. 50: 31-40.

Wei, L., Chen, Y., Zhang, B. and Zu, Z. (2013). Synthesis of highly selective zeolite topology molecular sieve for adsorption of benzene gas. Solid State Sci. 16: 39-44.

Wilson, S.T., Lok, B.M., Messina, C.A., Cannan, T.R. and Flanigen, E.M. (1982). Aluminophosphate molecular sieves: A new class of microporous crystalline inorganic solids. J. Am. Chem. Soc. 104: 1146-1147.

Yang, L., Qian, X., Yuan, P., Bai, H., Miki, T., Men, F., Li, H. and Nagasaka, T. (2019a). Green synthesis of zeolite $4 \mathrm{~A}$ using fly ash fused with synergism of $\mathrm{NaOH}$ and $\mathrm{Na}_{2} \mathrm{CO}_{3}$. J. Cleaner Prod. 212: 250-260.

Yang, X.L. and Zhang, J. (2011). Photochemical oxidation removal of $\mathrm{NO}$ and $\mathrm{SO}_{2}$ from simulated flue gas of coalfired power plants by wet scrubbing using $\mathrm{UV} / \mathrm{H}_{2} \mathrm{O}_{2}$ advanced oxidation process. Ind. Eng. Chem. Res. 50: 3836-3841.

Yang, Z., Ji, P., Li, Q., Jiang, Y., Zheng, C., Wang, Y., Gao, $\mathrm{X}$. and Lin, R. (2019b). Comprehensive understanding of $\mathrm{SO}_{3}$ effects on synergies among air pollution control devices in ultra-low emission power plants burning highsulfur coal. J. Cleaner Prod. 239: 118096.

Yao, Z., Xia, M., Ye, Y. and Zhang, L. (2009). Synthesis of zeolite Li-ABW from fly ash by fusion method. $J$. Hazard. Mater. 170: 639-644.

Yao, Z., Ji, X., Sarker, P., Tang, J., Ge, L., Xia, M. and Xi, Y. (2015). A comprehensive review on the applications of coal fly ash. Earth Sci. Rev. 141: 105-121.

Yaping, Y., Xiaoqiang, Z., Weilan, Q. and Mingwen, W. (2008). Synthesis of pure zeolites from supersaturated silicon and aluminum alkali extracts from fused coal fly ash. Fuel 87: 1880-1886.

Yordanov, I., Karatchevtseva, I., Chevreau, H., Avdeev, M., Holmes, R., Thorogood, G. and Hanley, T. (2014). Onestep approach for synthesis of nanosized $\mathrm{Cu}$-doped zeolite A crystals using the $\mathrm{Cu}-\mathrm{EDTA}$-complex. Microporous Mesoporous Mater. 199: 18-28.

Younas, M., Sohail, M., Leong, L., Bashir, M.J. and Sumathi, S. (2016). Feasibility of $\mathrm{CO}_{2}$ adsorption by solid adsorbents: A review on low-temperature systems. Int. J. Environ. Sci. Technol. 13: 1839-1860.

Yuan, G., Zhang, J., Zhang, Y., Yan, Y., Ju, X. and Sun, J. (2015). Characterization of high-alumina coal fly ash based silicate material and its adsorption performance on volatile organic compound elimination. Korean J. Chem. Eng. 32: 436-445.

Zeolite, N. (1997). Crystal structure determination of zeolite $\mathrm{N}$ from synchrotron X-ray powder diffraction data. Acta Chem. Scand. 51: 969-973.

Zhang, B., Chen, Y., Wei, L. and Zu, Z. (2012). Preparation of molecular sieve $\mathrm{X}$ from coal fly ash for the adsorption of volatile organic compounds. Microporous Mesoporous Mater. 156: 36-39.

Zhang, H., Chen, M., Shi, Z., Bu, X., Zhou, Y., Xu, X. and Zhao, D. (2001). Hydrothermal synthesis of new pure beryllophosphate molecular sieve phases from concentrated amines. Chem. Mater. 13: 2042-2048.

Zhang, J., Singh, R. and Webley, P.A. (2008). Alkali and alkaline-earth cation exchanged chabazite zeolites for adsorption based $\mathrm{CO}_{2}$ capture. Microporous Mesoporous Mater. 111: 478-487.

Zhang, L., Xin, Q., Lou, L., Li, X., Zhang, L., Wang, S., Li, Y., Zhang, Y., Wu, H. and Jiang, Z. (2019a). Mixed matrix membrane contactor containing core-shell hierarchical $\mathrm{Cu} @$ 4A filler for efficient $\mathrm{SO}_{2}$ capture. J. Hazard. Mater. 376: 160-169.

Zhang, S., Zhong, L., Chen, X., Liu, Y., Zhai, X., Xue, Y., Wang, W., Liu, J. and Xu, K. (2019b). Emissions characteristics of hazardous air pollutants from the incineration of sacrificial offerings. Atmosphere 10: 332.

Zhang, Z., Xiao, Y., Wang, B., Sun, Q. and Liu, H. (2017). Waste is a misplayed resource: Synthesis of zeolites from fly ash for $\mathrm{CO}_{2}$ capture. Energy Procedia 114: 2537-2544.

Zhou, L., Chen, Y.L., Zhang, X.H., Tian, F.M. and Zu, Z.N. (2014). Zeolites developed from mixed alkali modified coal fly ash for adsorption of volatile organic compounds. Materi. Lett. 119: 140-142.

Zhu, T., Dai, Y., Lu, L., Huang, Q., Shi, Y. and Zhou, J. (2013). Advances in biopurification technology of VOCs. Biotechnol. Front. 2: 37-41.

Received for review, December 24, 2019 Revised, March 29, 2020 Accepted, March 29, 2020 